\title{
The impact of student facilitation on student engagement in asynchronous online discussion
}

\author{
Robin Bowen \\ West Virginia University, robin.bowen@mail.wvu.edu
}

Follow this and additional works at: https://researchrepository.wvu.edu/etd

Part of the Online and Distance Education Commons

\section{Recommended Citation \\ Bowen, Robin, "The impact of student facilitation on student engagement in asynchronous online discussion" (2019). Graduate Theses, Dissertations, and Problem Reports. 3779. \\ https://researchrepository.wvu.edu/etd/3779 \\ This Dissertation is protected by copyright and/or related rights. It has been brought to you by the The Research Repository @ WVU with permission from the rights-holder(s). You are free to use this Dissertation in any way that is permitted by the copyright and related rights legislation that applies to your use. For other uses you must obtain permission from the rights-holder(s) directly, unless additional rights are indicated by a Creative Commons license in the record and/ or on the work itself. This Dissertation has been accepted for inclusion in WVU Graduate Theses, Dissertations, and Problem Reports collection by an authorized administrator of The Research Repository @ WVU. \\ For more information, please contact researchrepository@mail.wvu.edu.}


The impact of student facilitation on student engagement in asynchronous online discussion

\author{
Robin T. Bowen \\ Dissertation submitted \\ to the College of Education and Human Services \\ at West Virginia University \\ in partial fulfillment of the requirements for the degree of \\ Ed.D. in \\ Instrcutional Design and Technology
}

Jiangmei Yuan, Ph.D., Chair

Ugur Kale, Ph.D.

Suzanne Bell, Ph.D.

Department of Learning Sciences and Human Development

Morgantown, West Virginia

2019

Keywords: Engagement, Online discussion, Student facilitation, Peer assessment Copyright 2019 Robin T. Bowen 


\begin{abstract}
The impact of student facilitation on student engagement in asynchronous online discussion Robin T. Bowen
\end{abstract}

Lack of engagement in asynchronous online discussion is a common issue due to insufficient participation, disinterest in discussion, superficial discussion, and the influence of peer behaviors. The purpose of this study was to enhance student engagement in asynchronous online discussion by using student-led discussion and peer assessment. A mixed methods design was utilized in this study to offset quantitative and qualitative research weaknesses and to draw on the strengths of both (Plano Clark \& Creswell, 2008). The control group participated in the discussion managed by the instructor, who posted weekly discussion questions to a class discussion board and facilitated the discussion. The experimental group worked in smaller discussion groups, led by a different student each week who posed a discussion question, facilitated the group discussion, and conducted a peer review. Interviews and discussion post analysis showed that students were behaviorally engaged and the way in which they demonstrated cognitive and emotional engagement varied. Survey results indicated that there was no statistically significant difference in the control group and experimental groups' cognitive and emotional engagement, and academic performance. Students liked the student-led format, however, they preferred participating rather than leading. Directions for future research on student engagement in online discussion were identified. 


\section{Table of Contents}

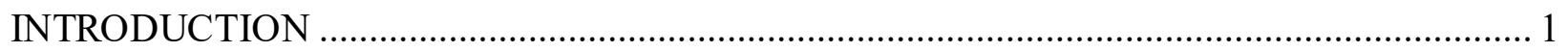

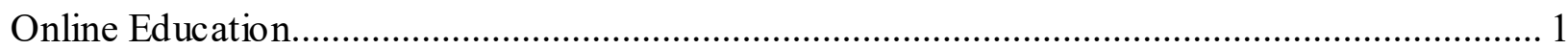

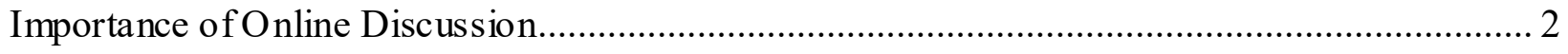

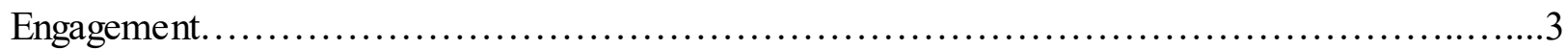

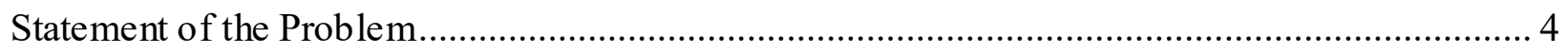

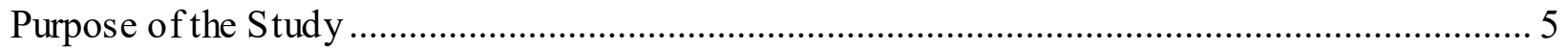

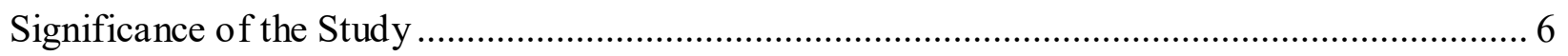

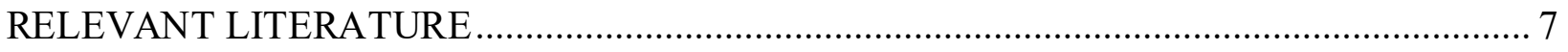

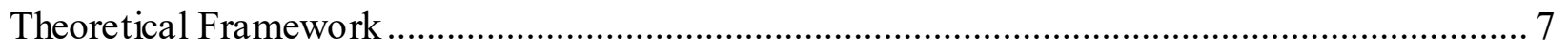

Previous Efforts in Increasing Engagement in Online Discussion ...................................... 9

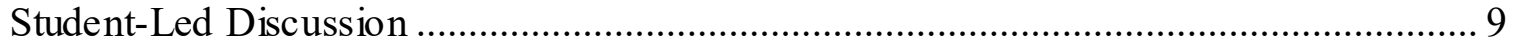

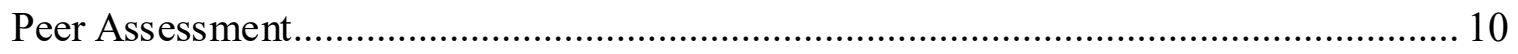

Other Strategies to Enhance Student Engagement in Online Discussion ........................ 11

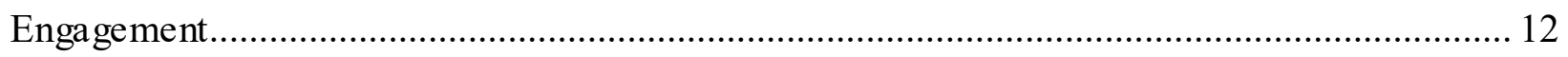

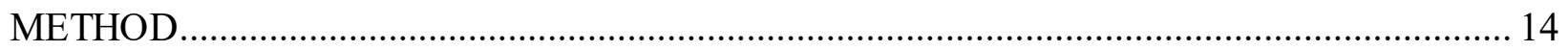

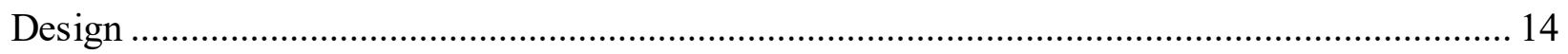

Block Design.............................................................. 15

Tests for RBD ANOVA Assumptions............................................ 16

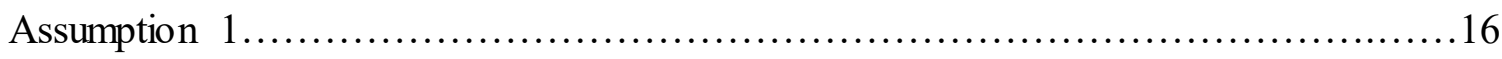

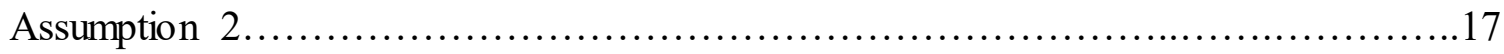

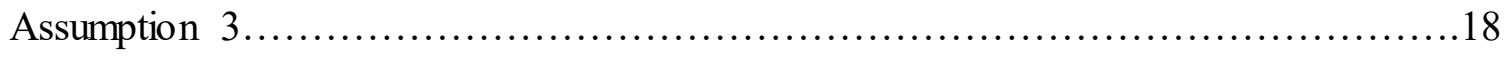

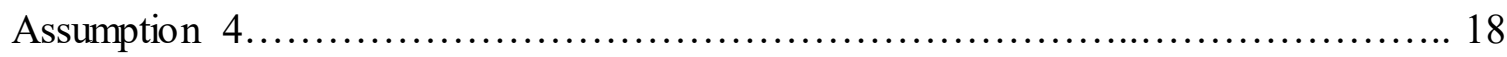




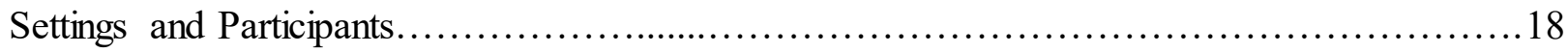

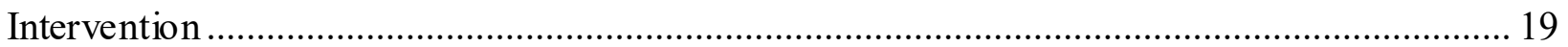

Discussion Facilitation Training................................................. 19

Post Synopsis Including Reflection and Discussion Questions...........................20

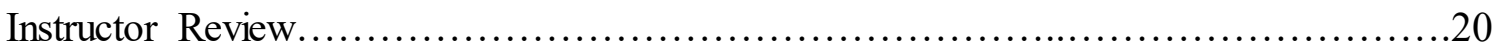

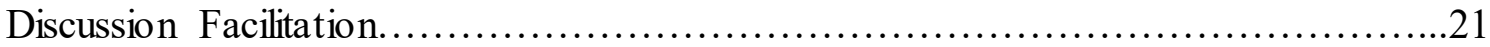

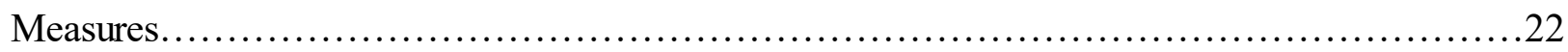

Behavioral engagement.......................................................................................... 22

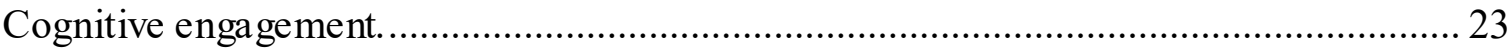

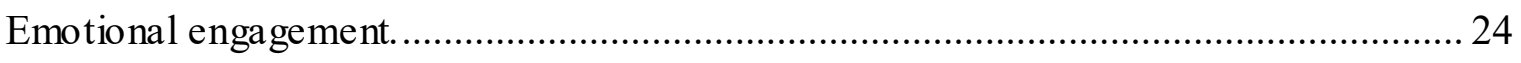

Academic performance .............................................................................................. 24

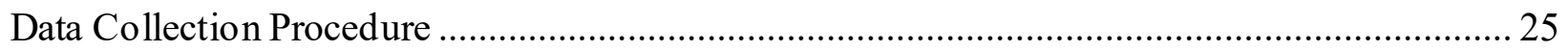

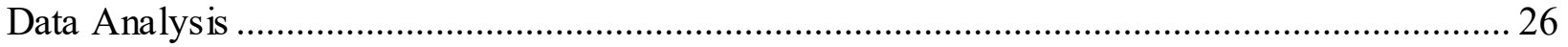

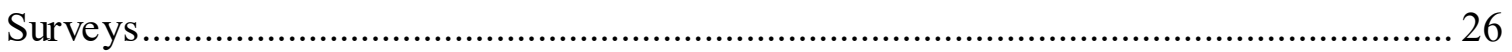

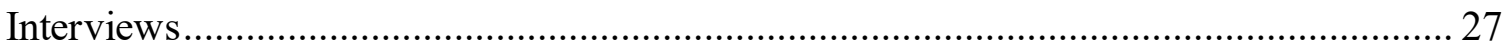

Online Discussion Posts and Comments.................................................................... 28

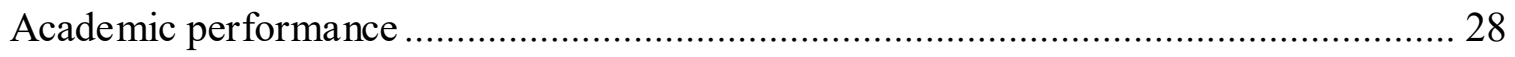

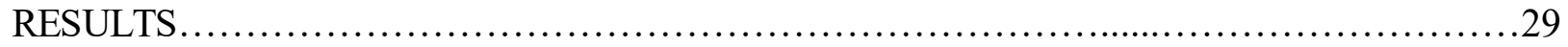

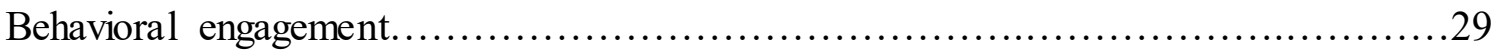

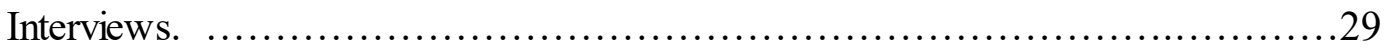

Numbers of original discussion posts and comments. .........................29

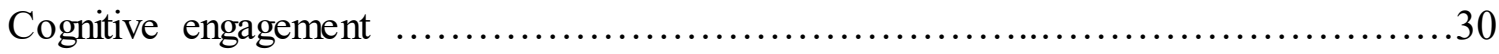

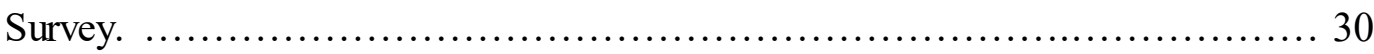

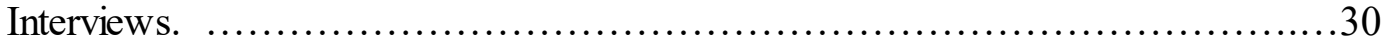

Discussion posts. ..................................................... 31 
Emotional engagement................................................... 32

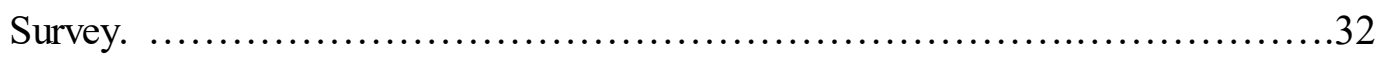

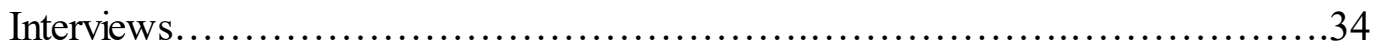

Academic Performance..........................................................

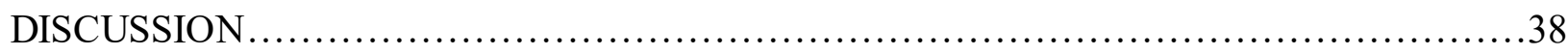

Summary of Findings....................................................... 38

RQ1: To what extent and in what ways did student-led discussion affect

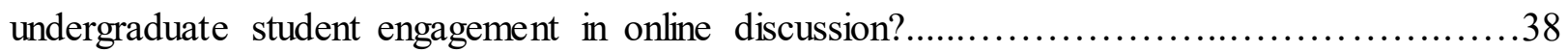

RQ2: To what degree did student-led discussion impact undergraduate students'

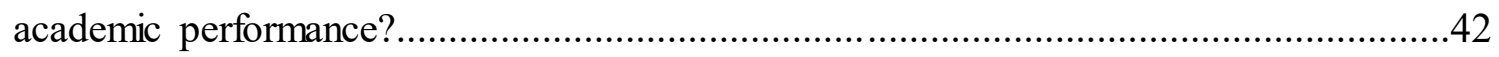

RQ3: How did peer assessment impact undergraduate student engagement in

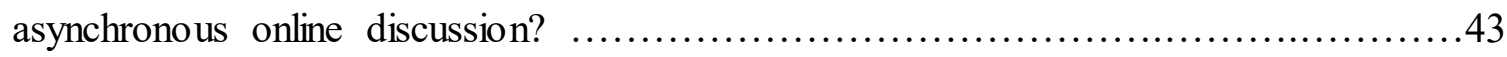

Research Limitations and Future Research Directions............................43

Conclusion...........................................................44

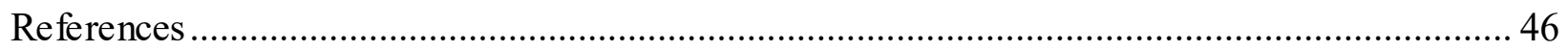




\section{APPENDICES}

Appendix A: Elements of Critical Thinking.......................................59

Appendix B: Interview Questions..............................................60

B1: Control Group (CG) Interview Questions.................................60

B2: Experimental Group (EG) Interview Questions..............................61

Appendix C: Surveys..........................................................63

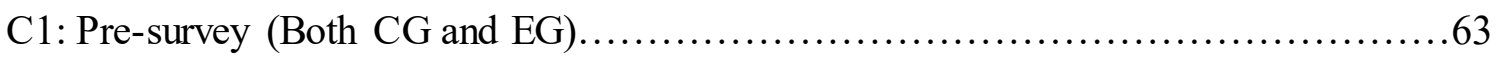

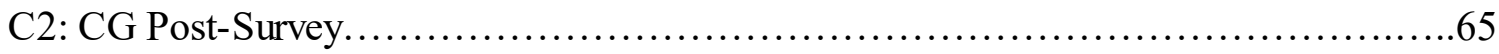

C3: EG Post-Survey.................................................67

Appendix D: Rubrics...................................................... 70

D1: Rubric to Evaluate Leaders Initial Submission.................................. 70

D2: Rubric to Evaluate Leaders Facilitation................................... 71

D3: Rubric to Evaluate Other Participants' Performances........................... 71

Appendix E: Cognitive and emotional engagement survey results by block.................72

Appendix F: Randomized Block Design.......................................... 73 


\section{LIST OF TABLES}

Table 3.1: Results of Shapiro-Wilk Normality Tests................................... 17

Table 3.2: Results of Levene's Test of Homogeneity of Variance........................... 17

Table 3.3: Instruments to Measure Cognitive and Emotional Engagement and a Sample Item of

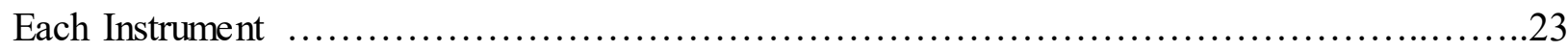

Table 3.4: Data Collected and Data Analysis Method for the Dependent Variables..............26

Table 4.1: Average numbers of original discussion posts and comments per participant every

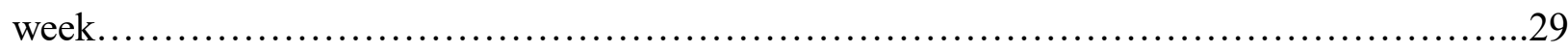

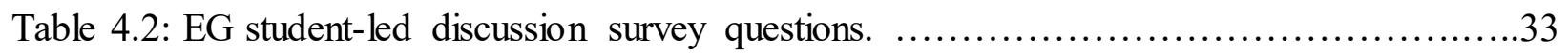

Table 4.3: Average grades of the CG and the EG participants per discussion..................37

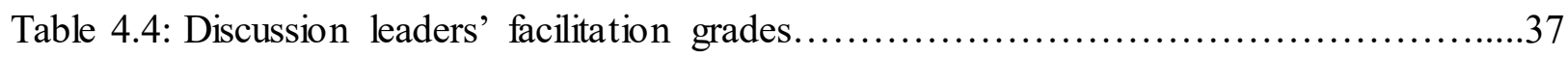




\section{LIST OF FIGURES}

Figure 3.1. Sequential Mixed Methods Design..........................................15

Figure 3.2. The Process of Student-Led Discussion and Peer Assessment.........................21

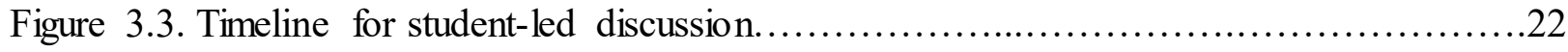

Figure 4.1. Histograms of highly emotional responses..................................... 


\section{Chapter I}

\section{INTRODUCTION}

\section{Online Education}

Online learning has become very popular and important in higher education. As of 2018, enrollment in at least one online course accounted for approximately 31.6 percent of the total enrollment in United States higher education institutions (Seaman, Allen, \& Seaman, 2018). Online class offerings at colleges and universities have been increasing by ten percent or more each year for over fourteen years since 2003 (Forte, Schwandt, Swayze, Butler, \& Ashcraft, 2016; Seaman et al., 2018). Online learning is a critical component of strategic planning in higher education, according to 69.1 percent of academic leaders, while conversely, 11.2 percent of academic institutions stated that online education is not important for their long-term strategic planning (Allen \& Seaman, 2013).

Online education is beneficial for learners. It provides better access to education for many people because they can participate whenever and wherever (Mayadas, Bourne, \& Bacsich, 2009; Reese, 2015). The flexibility in terms of time affords students the convenience to attend to personal responsibilities while still balancing coursework (Ilgaz \& Gülbahar, 2015) and being able to access the courses at any place reduces travel costs (Moody, 2004). In addition, learners can receive more individual attention from the instructor if effective means of communication are utilized (Moody, 2004). Also, learners have more time to respond to questions in online classes than in traditional face-to-face classes, which allows learners to better craft their responses and increase their confidence (Bawa, 2016; Moody, 2004).

Enrollment in online courses is increasing, yet attrition rates are $10-20 \%$ higher than in face-to-face courses (Angelino, Williams, \& Natvig, 2007; Carr, 2000; Moody, 2004). The 
possible reasons for high attrition rate include a lack of student engagement, a perceived loss of relationship-building between teachers and students, a lack of technical competency, and a lack of learning communities (Cochran, Campbell, Baker, \& Leeds, 2014; E. Lee, Pate, \& Cozart, 2015; Moody, 2004). Time management and technical difficulties with courses also lead to students' withdrawal from online courses (Ilgaz \& Gülbahar, 2015).

\section{Importance of Online Discussion}

Online discussion is critical for online courses as it is the primary way for students to engage with peers and instructors (Lundberg \& Sheridan, 2015). Online discussion serves as a helpful tool in students' online learning process and overall experience in several ways (Surrette \& Johnson, 2015)(J.-M. Lee, 2006). First, it provides a mechanism for supporting interactions. There are three forms of interaction which are student-student interaction, student-instructor interaction, and student-content interaction (G. E. Moore, Warner, \& Jones, 2016). These interactions can establish meaningful communication (Dixon, 2014), contribute to a greater sense of community (Buckley, 2011; Hammond, 2017; Moody, 2004), result in critical thinking and new knowledge construction (Chen, Chang, Ouyang, \& Zhou, 2018; Williams \& Lahman, 2011; Zhu, 2006), and lead to enhanced student engagement in online education (Dixson, 2010; G. E. Moore et al., 2016). Second, online discussion motivates students to have more in-depth discussion and compose more thoughtful responses than discussion in a traditional face-to-face class because students have more time to process and thoroughly think through the information (Buckley, 2011; Gao, Zhang, \& Franklin, 2013; E. Lee \& Hannafin, 2016). Studies show that students demonstrate greater success in course preparation (Lineweaver, 2010; Salter \& Conneely, 2015a) and understanding of course materials (Lineweaver, 2010) when required to discuss concepts in a forum with their peers (Lineweaver, 2010; Salter \& Conneely, 2015b). The 
degree and quality of student participation and reflection improve when they engage in online discussion (Buckley, 2011; Williams \& Lahman, 2011). Third, online discussion motivates students, especially shy students to participate in discussion (J.-M. Lee, 2006). Students who do not typically participate in a face-to-face class may be more inclined to engage in online discussion (Asterhan \& Eisenmann, 2011; Kurnaz, Ergün, \& Ilgaz, 2018; Ng, Cheung, \& Hew, 2012; Salter \& Conneely, 2015a) or as William and Lahman state, the students "shine while online” (Williams \& Lahman, 2011, p.158).

\section{Engagement}

Engagement can be broken down into three types which are behavioral, cognitive, and emotional engagement (Fredricks, Blumenfeld, \& Paris, 2004). Behavioral engagement can be described as students' participation in academic activities and is an essential type of engagement for retention in classes (Fredricks et al., 2004). Students are not behaviorally engaged in online discussion. They do not make posts before the deadline (Skinner, Furrer, Marchand, \& Kindermann, 2008), skip posting altogether (Fredricks \& McColskey, 2012), post messages that are irrelevant (Hou \& Wu, 2011), and do not read or comment on their peers' posts as required (S. Christenson, Reschly, \& Wylie, 2012).

Cognitive engagement can be defined as students' perseverance or level of investment and willingness to do what is more than necessary to comprehend the learning materials (Fredricks et al., 2004; Parsons, Nuland, \& Parsons, 2014; Pickering, 2017). Students' lack of cognitive engagement in online discussion is exhibited by a lack of quality (Hew \& Cheung, 2003), originality (Kurnaz et al., 2018), critical thinking (Hew \& Cheung, 2003; Hew, Cheung, \& Ng, 2010; Wickersham, L., \& Dooley, K., 2006), and depth of interaction (De Wever, Keer, Schellens, \& Valcke, 2010; Kurnaz et al., 2018). Also, students are not willing to put forth effort 
to master concepts (Fredricks et al., 2004; Fredricks \& McColskey, 2012). Students may feel that discussion topics are not interesting nor worthy of discussion (Zhao, Sullivan, \& Mellenius, 2014). When students are disinterested in the discussion, they may respond with superficial comments such as "I agree" (Hew et al., 2010) or "me too" (Hew et al., 2010; Murphy \& Coleman, 2004). Such superficial discussion demonstrates a lack of cognitive engagement. Similarly, when there is a lack of critical thinking, students may share the conclusions or judgments of peers without challenging or expanding them, also showing a deficit in cognitive engagement (Hew \& Cheung, 2003).

Emotional engagement denotes students' feelings and reactions to things which are occurring within the classroom (Fredricks et al., 2004), and may be viewed as their habits of mind (Cheung \& Hew, 2010). Students' lack of emotional engagement in online discussion is exhibited in several ways. Sometimes, they perceive their peers' online discussion behaviors to be arrogant or discussion posts to be extraneous (Nandi, Hamilton, \& Harland, 2012). They tend to feel secluded in online discussion forums (J.-M. Lee, 2006). When students' posts lack substance, some of their peers lose interest in the discussion (Hew et al., 2010). Many students do not realize the potential value of discussion and do not feel that discussion posts are an important learning activity (Dennen, 2008).

\section{Statement of the Problem}

Although online discussion is critical for online courses, students tend not to engage in online discussion. Lack of engagement in asynchronous online discussion is a common issue due to insufficient participation, disinterest in the discussion, superficial discussion, and the influence of peer behaviors (Hew et al., 2010). Sometimes students do the minimum work possible to fulfill course discussion requirements (Dennen, 2008), exaggerate posts or responses to feign 
substance (Kurnaz et al., 2018), and resort to shallow discussion (Wise, Perera, Hsiao, Speer, \& Marbouti, 2012). Peer facilitation provides a mechanism for students to interact with each other, which may enhance student engagement in online discussion (Baran \& Correia, 2009). Prior studies have shown the positive influence of peer facilitation on online discussion (e.g., Baran \& Correia; Chan, Hew, \& Cheung, 2009; De Wever, 2010; De Wever, Keer, Schellens, \& Valcke, 2010; Hew \& Cheung, 2011). Research has also demonstrated the positive impact peer assessment exert on online discussion (e.g., Ertmer et al, 2007; Ertmer et al, 2010; Mwalongo, 2013; Wang, Hou, \& Wu, 2017). However, no study has combined peer facilitation and peer assessment, and has used peer assessment specifically to enhance students' cognitive engagement.

\section{Purpose of the Study}

The purpose of this study is to enhance student engagement in online discussion by having students lead a discussion, and ask questions to help their peers become more cognitively engaged after assessing their peers' cognitive engagement in online discussion. For simplicity, the term student-led discussion is used to refer to the peer facilitation and peer assessment mechanism (detailed in Chapter III) employed in this study. The research questions addressed were:

1. To what extent and in what ways did student-led discussion affect undergraduate student engagement in online discussion?

2. To what degree did student-led discussion impact undergraduate students' academic performance?

3. How did peer assessment impact undergraduate student engagement in asynchronous online discussion? 


\section{Significance of the Study}

The purpose of this study is to enhance student engagement in asynchronous online discussion by using student-led discussion. Asynchronous online discussion is regularly used at every academic level (Picciano, 2002), so it is important that students are engaged and learning in order to maximize the educational benefits for the learners. Students tend to not engage in online discussion, rather they try to meet the minimum requirement for discussion posts, and sometimes, they do not even meet the requirement (Fredricks \& McColskey, 2012). Engagement has a direct link to learning, so increasing student engagement is important for learners (S. Christenson et al., 2012; Hew et al., 2010). This study will explore a possible way to enhance engagement in asynchronous online discussion with the use of student-led discussion and peer assessment. The study will focus on behavioral, cognitive, and emotional engagement elements as these elements influence factors such as enjoyment, participation, interaction, and degree of learning in courses. When students have a strong sense of engagement, they are more successful in courses (S. Christenson et al., 2012; Williams \& Lahman, 2011). This study will highlight the design of a student-led discussion, including an element of peer assessment, to enhance engagement and will provide implications for researchers and practitioners. 
Chapter II

RELEVANT LITERATURE

This chapter reviews the theoretical frameworks providing support for student-led discussion, previous efforts made by prior studies to increase student engagement in online discussion, and what engagement means. First, the chapter explores relative theoretical frameworks, including self-regulated learning, cognitive congruence, and social congruence. Next, the chapter reviews previous studies that used various strategies to enhance student engagement in online discussion. The studies using student-led discussion and peer assessment are reviewed in detail. However, research employing other strategies to enhance student engagement in online discussion is also explored for the purpose to provide a broader understanding of what efforts prior studies have made. Finally, this chapter explains the engagement lens through which online discussion was examined.

\section{Theoretical Frameworks}

Self-regulated learning and cognitive and social congruence theories provide support for student-led online discussion. Self-regulated learning is defined in terms of the learner demonstrating personal initiative and self-generated thoughts, feelings, and actions, in pursuing their own goals (Zimmerman \& Pons, 1986). Winne (1995) described self-regulated learning as an inherently beneficial and self-directed process of learning. Recent studies have highlighted the value of self-regulated learning in online course discussion, which includes increased student responsibility, engagement in learning, and reflection on interactions and learning tasks (Dabbagh \& Kitsantas, 2005). When students lead online discussion, they are involved in selfregulated learning because they need to take initiative to facilitate online discussion and use their knowledge to generate discussion questions. Students also have the autonomy to direct the 
discussion in the way that best fits their learning style and understanding of the content, and autonomy promotes self-regulated learning (Sierens, Vansteenkiste, Goossens, Soenens, \& Dochy, 2009).

The term "cognitive congruence" was created by Cornwall (Cornwall, 1979) in his description on why peer tutors may be superior to faculty in helping learners master concepts (Yew \& Yong, 2014). Cornwall argued that peer tutors had a similar knowledge base and cognitive process as the students, which enabled peer facilitators to communicate in a way that students could easily grasp (Cornwall, 1979). Cognitive congruence leads to an effective peerassisted educational experience (Lockspeiser, O’Sullivan, Teherani, \& Muller, 2008). When students lead online discussion, the leaders are likely to express themselves in a way that is familiar to their peers, which would make it easy for their peers to understand their points of view.

Student-led asynchronous online discussion creates a social congruence between student leaders and their peers because they have similar social roles in the class, which allows them to relate to one another more easily, and enables students to learn from their peers' successes and challenges presented by the content (Lockspeiser et al, 2008; F. Moore, 2017).(Lockspeiser et al., 2008) Social congruence helps student leaders become more cognitively congruent with their peers and facilitates performance more directly (Schmidt \& Moust, 1995). There are cognitive and emotional benefits of social congruence in student-led online discussion because it may help the students who are being led by their peers to feel less intimidated, making them more willing to participate in discussion by sharing their thoughts on the topics. 


\section{Previous Efforts in Increasing Engagement in Online Discussion}

Researchers have employed various strategies to improve student engagement in online discussion. This section reviews the strategies used in prior empirical studies. Student-led discussion and peer assessment strategies are explored in detail, and studies on other strategies are also briefly reviewed.

\section{Student-Led Discussion}

Another strategy to enhance engagement in online discussion is to have students lead the discussion. Student-led facilitation sets the tone for increased student attention, enthusiasm, and engagement in online discussion (Baran \& Correia, 2009). Students are less passive and more motivated (Dröge \& Spreng, 1996). Student-led discussion enhances student involvement and satisfaction while enabling better career preparation, use of time, and achievement of goals (Dröge \& Spreng, 1996). Student leaders have a higher level of achievement when they are given the responsibility of leading (Zha \& Ottendorfer, 2011).

Empirical studies show the positive impact of student facilitation on learning. Baran \& Correia (Baran \& Correia, 2009) explored student-led facilitation strategies and found that these discussions resulted in more original ideas, encouraged student participation, and created a relaxed environment. De Wever (2010) assigned students with discussion facilitation roles. Student leaders played the roles of starter, summarizer, and moderator, which resulted in higher levels of knowledge construction. The study conducted by Ioannou, et al. (2014) combined the ideas of quality discussion and student facilitation to examine the impact on knowledge construction, or cognitive engagement. Student facilitated discussion has been shown to have a positive influence in online courses; students seem to prefer it, there is increased discussion, and it has had a direct impact on the quality of discussion (Ioannou et al, 2014). Increased 
engagement is observed when peer facilitators show appreciation for participants' contribution to discussion, show interest in a range of viewpoints, pose questions or requested elaboration, and give alternate suggestions or raised concerns ( $\mathrm{Ng}$ et al, 2012).

Research shows that how effectively student leaders facilitate discussion affects other students' participation (Zha \& Ottendorfer, 2011). It is important that all students are given the chance to lead over the course of the class (Zha \& Ottendorfer, 2011). Discussion threads grow and are sustained when student leaders use facilitation techniques such as pointing, questioning, resolving, and summarizing (Chan, Hew, \& Cheung, 2009). It is important for student facilitators to interact with posts by agreeing, disagreeing, and/or sharing opinions to maintain student interest (Hew \& Cheung, 2011). What is also critical is the amount of communication and social interaction that takes place through student-led discussion (Ioannou et al., 2014). Depth of cognition is also important and may be directly related to questioning and thread development (Chan et al., 2009).

\section{Peer Assessment}

Several studies attempted to enhance online discussion by using peer assessment. Peer assessment can enhance face-to-face discussion (Boud, 1995), so it is important to explore how that translates to an online discussion environment (Kulkarni et al., 2013). In a review of research on online discussion posts in higher education Hammond noted that peer assessment is considered a best practice (Hammond, 2017). In Ertmer et al.'s study (Ertmer et al., 2007), peer feedback was provided to students' online discussion in the form of a numerical score based on Bloom's taxonomy and descriptive comments to support the score. The peer feedback had a direct positive impact on the students' shared learning and knowledge construction. Students experienced higher level cognitive processes within the peer review steps. In Ekahitanond's 
study (2013), students gave feedback to their peers' online discussion posts, guided by the critical inquiry model based on Bloom's cognitive levels and collaborative learning. Peer assessment created greater cognitive process (Wang, Hou, \& Wu, 2017), learning success, and a more positive attitude toward learning (Nguyen, 2017).

\section{Other Strategies to Enhance Student Engagement in Online Discussion}

Other strategies used to enhance student engagement include creating a course design rubric to establish standards of quality for the online course in general and also for online discussion (Jaggars \& Xu, 2016), facilitating students' reflection on discussion data and content by using social learning analytics (Chen et al, 2018), gamifying online discussion (Ding, Kim, \& Orey, 2017; Domínguez et al., 2013; Goehle, 2013), and using various methods such as clearly explaining discussion purpose, requiring posting deadlines, and providing incentives in the form of grades (Hew et al., 2010).

Some studies used various discussion facilitation strategies to improve online discussion. The first type of facilitation strategy was assigning specific roles or parts to students to play in the discussion (Yuan \& Kim, 2014). For example, in a group of four students, one may act as the facilitator, one as the researcher, one as the motivator, and one as the person responsible for tying everything together. When instructors assign roles as a facilitation strategy, it does not diminish their presence in the discussion (Baran \& Correia, 2009). Second, the devil's advocate strategy can be useful. The strategy requires students to selectively deceive each other and potentially argue a point that they do not believe for the sake of deeper discussion and enhanced critical thinking (Duran \& Fusaroli, 2017). Third, debates allow students to constructively challenge one another for learning through discussion (Pilkington \& Walker, 2003). Fourth, case 
studies, can be used to examine events that cannot be controlled in a real-world context (Nandi et al., 2012; Yin, 1994).

\section{Engagement}

Engagement in reference to learning is represented by a student's effort and commitment in their learning, where involvement is the critical element (Axelson \& Flick, 2011; Kahn, Everington, Kelm, Reid, \& Watkins, 2017). Engagement promotes success. If students are engaged, they are less likely to fail (S. Christenson et al., 2012). With those successes, students are more likely to feel more confident and connected academically and socially, thus resulting in more positive interactions (S. Christenson et al., 2012) and greater comfort levels in their learning environment (R. L. Moore, 2014). Engagement is an important concept within the study of education. It contributes to students' overall academic development (S. Christenson et al., 2012).

Fredricks et al. (2004) proposed three dimensions of engagement, which are behavioral, cognitive, and emotional engagement. Behavioral engagement can be described as a student's participation in academic activities (Fredricks et al., 2004). It is demonstrated by students' behaviors such as effort, attention, attendance, and positive student conduct (Fredricks et al., 2004). Behavioral engagement contributes to students' knowledge and desire to explore further (Meyer, 2014) and leads to learning (Fredricks et al., 2004). Additionally, behavioral engagement may occur when students model an instructor's participation in the learning environment, such as a teacher's contribution in an online discussion forum (Shea, Sau Li, \& Pickett, 2006). It is important to establish models that lead to increased student participation and establish procedures to support engagement (McCrory, Putnam, \& Jansen, 2008). 
Cognitive engagement deals with students' task mastery (S. Christenson et al., 2012). It can be defined as a student's perseverance or level of investment and willingness to do what is more than necessary to comprehend the learning materials (Fredricks et al., 2004; Parsons et al., 2014; Pickering, 2017). Indicators of cognitive engagement include the level of student motivation, ability to self-direct learning in a strategic manner, problem solving, hard work, preference for a challenge, and mastery of course materials (Fredricks et al., 2004; Schlenker, Schlenker, \& Schlenker, 2013). A student who is cognitively engaged will be able to fully understand learning objectives and how to achieve those with the resources available to them (Pickering, 2017).

Emotional engagement denotes students' feelings and reactions to things which are occurring within the classroom (Fredricks et al., 2004). It can also be described as the emotional value and connections students create in the classroom (Fredricks et al., 2004). Emotions serve many purposes in the learning environment, including encouraging or hindering cognitive and behavioral engagement and achievement (Marchand \& Gutierrez, 2012). Indicators of emotional engagement include student reaction, enjoyment, value, pride, anger, anxiety, shame, and boredom (Fredricks et al., 2004). When students respond favorably to the content and instructor, the material is perceived as meaningful and allows students to learn rather than memorize (Tripathi \& Dewan, 2017). Conversely, if students exhibit negative emotions toward an instructor or course content, they are less likely to learn the associated material (Yuan \& Kim, 2017). 


\section{Chapter III}

METHOD

\section{Design}

A mixed methods design was utilized in this study. There were two rationales for the use of mixed methods. The primary rationale was to offset quantitative and qualitative research weaknesses to draw on the strengths of both (Plano Clark \& Creswell, 2008). The strengths of quantitative research include finding trends and making generalization and those of qualitative methods include having a small sample size and identifying details in depth (Creswell \& Clark, 2007). For this study, an a priori power analys is was conducted using G*Power 3.1.9.4 (Faul, Erdfelder, Lang, \& Buchner, 2007). An a priori power analysis with an alpha of 0.05 and a small-sized effect $(f=0.10)$ showed that the minimum sample size to achieve a small-sized effect must have been 788. An a priori power analysis with an alpha of 0.05 and a medium-sized effect $(f=0.25)$ showed that the minimum sample size to achieve a medium-sized effect must have been 128. An a priori power analys is with an alpha of 0.05 and a large-sized effect $(f=0.4)$ showed that the minimum sample size to achieve a large-sized effect must have been 52 . The sample size of this study was 78 . To offset the weakness of the small sample size, qualitative data, including interviews and discussion posts, were collected, to yield an in-depth understanding of students' engagement. Meanwhile, the expectation was that quantitative results from surveys would show a trend of student engagement in online discussion.

The secondary rationale for utilizing a mixed methods design was that the quantitative and qualitative research can answer different research questions (Plano Clark \& Creswell, 2008). RQ1 is a mixed methods research question, RQ2 is quantitative in nature, and RQ3 is qualitative in nature. 
The mixed methods in this study was a sequential design (see Figure 3.1). The sample size of this study was 78 and its power was .59. A randomized block design was used, which was one of the ways suggested by Festing (2014) to increase power. In this study, a block consisted of one discussion group in the experimental group (Appendix F). There were a total of 12 blocks. The qualitative data, interviews and discussion posts, were analyzed and reported per block. Therefore, the mixing was structural. The quantitative and qualitative data were collected at the same time. Priority was given to the qualitative data.

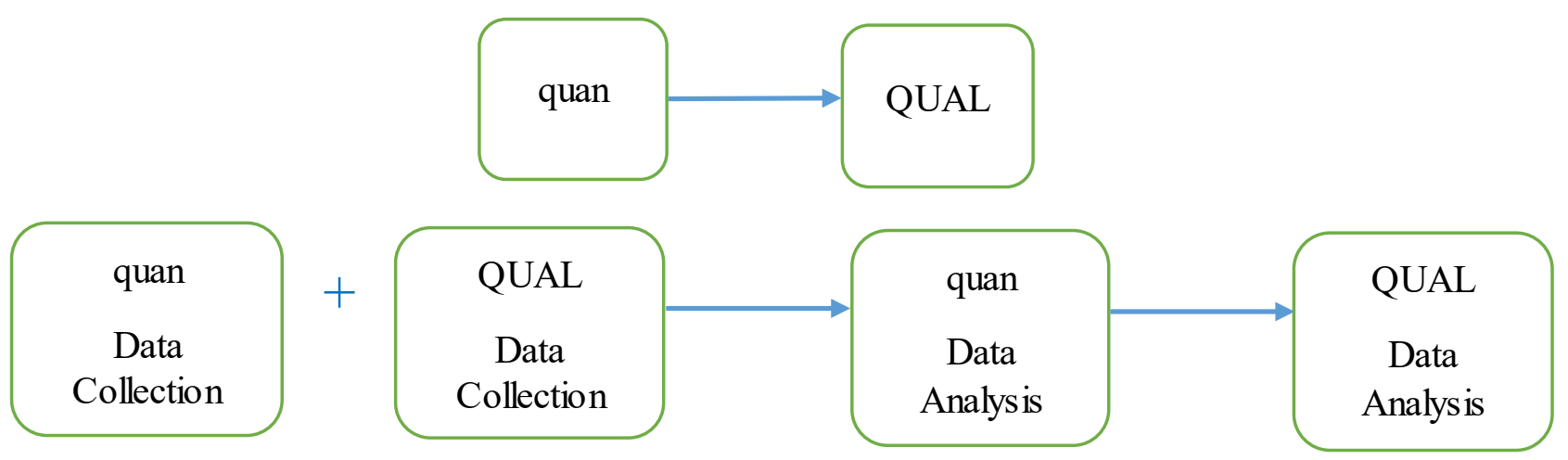

Figure 3.1. Sequential mixed methods design.

\section{Block Design}

A randomized block design was used to reduce variability within treatment conditions and provide a better estimate of the treatment effects (Shieh \& Show-Li, 2004). This study included a number of potential contributing factors that may have influenced the results. Randomized block designs were intended to minimize the impact of these nuisance variables. For example, it was unknown if factors such as a students' major, gender, or level of schooling may have influenced their level of engagement. Since participants were randomly assigned to blocks by the learning management system, the analysis could not be blocked by these factors. Randomized block analysis is designed to address this by creating homogeneous blocks such that the variation within the blocks is less than the variation between the blocks. While block design 
can increase power, if steps are not taken to reduce the experimental error then the study could lose power. Power could be negatively impacted when the study has a small sample size as the power analysis relies on an estimate of the standard deviation, which will not be as informative in very small samples (Festing, 2014).

The regression equation associated with the model of this randomized block design is $\mathrm{Y}_{i, j}$ $=\mu+\mathrm{T}_{i}+\mathrm{B}_{j}+$ random error, where $\mathrm{Y}_{i, j}$ is any observation that accounted for the primary factor of engagement and the blocking factor of discussion groups. $\mu$ is the mean. $\mathrm{T}_{i}$ is the effect of having been in the discussion. $\mathrm{B}_{j}$ is the effect of having been in the block or discussion group. Since potential nuisance variables are not known, the randomized block design was utilized.

\section{Tests for RBD ANOVA Assumptions}

ANOVA analysis is based on three assumptions regarding the underlying data:

1) The data is normally distributed

2) There is homogeneity of variances

3) The observations are independent of each other

4) There are no significant interactions between factors

For cognitive engagement and behavioral engagement, including anxiety, shame, boredom, pride, anger, and enjoyment one-way ANOVA tests were conducted. Four ANOVA assumptions were tested.

\section{Assumption 1 (Normal distribution)}

The Shapiro-Wilk normality test was utilized to test whether observations were normally distributed within each group. As shown in Table 3.1, the post-survey of cognitive engagement, and behavioral engagement, including anxiety, shame, boredom, pride, anger, and enjoyment of the EG group were not normally distributed. 
Table 3.1

Results of Shapiro-Wilk Normality Tests

\begin{tabular}{llccc}
\hline & $\begin{array}{c}\text { Shapiro-Wilk } \\
\text { Statistic }\end{array}$ & df & Sig. \\
\hline Cognitive & 0.94 & 78 & .001 \\
engagement & & & \\
Anxiety & 0.93 & 78 & .001 \\
Shame & 0.90 & 78 & .000 \\
Boredom & 0.96 & 78 & .007 \\
Pride & 0.93 & 78 & .000 \\
Anger & 0.94 & 78 & .002 \\
Enjoyment & 0.97 & 76 & .127 \\
\hline
\end{tabular}

\section{Assumption 2 (Homogeneity of variance)}

Levene's test was employed to test if the variables in each group had equal variances (Field, 2013). As shown in Table 3.2, Levene's test results revealed that the assumption of homogeneity of variance was satisfied for cognitive engagement, anxiety, boredom, pride, anger, and enjoyment. The assumption of homogeneity of variance was not satisfied for shame and enjoyment.

Table 3.2

Results of Levene's Test of Homogeneity of Variance

\begin{tabular}{lcccc}
\hline & $\mathrm{F}$ & $\mathrm{df1}$ & $\mathrm{df2}$ & Sig. \\
\hline Cognitive engagement & 2.55 & 2 & 75 & .085 \\
Anxiety & 2.604 & 2 & 75 & .081 \\
Shame & 4.111 & 2 & 75 & .020 \\
Boredom & 2.510 & 2 & 75 & .088 \\
Pride & 3.059 & 2 & 75 & .053 \\
Anger & 2.690 & 2 & 75 & .074 \\
Enjoyment & .601 & 1 & 74 & .441 \\
\hline
\end{tabular}




\section{Ass umption 3 (Independence of observation)}

Participants between the CG and the EG did not have a chance to talk to each other, they did not know which group they were in, and the CG and the EG took place in different semesters. All observations were independent within and between groups. The assumption of independence of observation was satisfied.

\section{Assumption 4 (No interaction between factors)}

It is reasonable to assume that the block factor and treatment factor did not interact as participants were randomly assigned to the block factor by the learning management system.

\section{Settings and Participants}

Participants consisted of 78 undergraduate Forensic and Investigative Science minors enrolled in four sections of a required course taught by the researcher at a public university in the Appalachian region of the Southern United States. The control group (CG) and experimental group (EG) included two sections, respectively. The course introduced forensic science professional duties, standards for professional behaviors, and influences different professional cultures exert on one another. The course was offered in an online, asynchronous format. All but one participant had taken at least one online class prior to taking this one, and $94.8 \%$ had previously participated in online discussion. The majority of the participants were majoring in Criminology (51.9\%), Psychology (11.7\%), and Multidisciplinary Studies $(9.1 \%)$. The rest of the participants reported that their intended major was Global Supply Chain Management, Biology, Accounting, Medical Laboratory Science, Sociology, Strategic Communications, International Studies, Electrical Engineering, Health Informatics and Information Management. Among the participants, $37.7 \%$ were in their third year; $33.8 \%$ were in their fourth year; and $20.8 \%$ were in their second year. The remaining participants $(7.8 \%)$ were in their fifth year. The majority of the 
participants were female $(72.7 \%)$ with 21 being male $(27.3 \%)$. Sixty-seven participants were white $(87 \%)$; three were black (3.9\%); four were multiracial $(5.2 \%)$, and three considered themselves as "other" (3.9\%). The participants' ages range from 19 to 52, with an average age of 21. The CG and the EG participants' GPAs before taking this course were not statistically significantly different, as shown by a dependent sample $t$-test $(t=-.177, p=.228, r=-.02)$.

\section{Intervention}

This study utilized student-led discussion to enhance student engagement in online discussion, which took place on a discussion board of the learning management system adopted by the university. The CG participated in the discussion managed by the instructor, who posted weekly discussion questions to a class discussion board and facilitated the discussion. The CG participants were responsible for answering the discussion questions posed by the instructor and responding to at least one peer's original post. All CG participants interacted in a class discussion board where they could access all of their peers' original posts and comments. The EG's discussion was managed by student leaders. The EG participants worked in discussion groups of five participants, considered blocks, in accordance with the randomized block design. Each group consisted of five randomly selected participants because, every week, one participant led the discussion in that group. A group with five participants allowed each participant to lead a discussion once during the five-week study period. The researcher assigned the order of leaders within the blocks based on an alphabetical order. A detailed description of the student-led discussion is presented in the following paragraphs.

\section{Discussion Facilitation Training}

To prepare participants to facilitate discussion, at the beginning of the semester, the instructor provided a discussion facilitation training via a mandatory asynchronous session. The 
training focused on four facilitation strategies, including case study, role play, debate, and devil's advocate. Explanations of the strategies and how to use them were detailed in the training. The four discussion strategies were selected because of their applicability to the subject matter of ethics. Case study and role play provided students with real-life situations, which empowered them to analyze issues and solve practical problems (Sadaf \& Olesova, 2017), and encouraged thinking from broader perspectives (Cornelius, Gordon, \& Harris, 2011). Debate and devil's advocate allowed participants to critically think about the materials and apply the knowledge that they had gained by simulating ethical issues professionals may encounter and encouraging empathy for alternate points of view (Duran \& Fusaroli, 2017; Pilkington \& Walker, 2003).

\section{Post Synopsis Including Reflection and Discussion Questions}

Each week student leaders (a) provided a brief synopsis and a reflection of the weekly readings, (b) posed a question for their peers to discuss, and (c) facilitated the discussion (see Figure 1). They submitted to the instructor the synopsis including a reflection, two to three potential discussion questions, and the discussion facilitation strategy they intended to use one week in advance. The strategy was selected from the list presented by the instructor.

\section{Instructor Review}

The instructor provided feedback on the synopsis with reflection, discussion questions, and facilitation strategy. In order to avoid influencing the student leaders, the feedback focused on the breadth of content of the synopsis and reflection, and the ability for the proposed discussion questions and facilitation strategy to encourage discussion. To be specific, the instructor made sure that the synopsis included a reflection and covered the main ideas from the readings, the discussion questions were open-ended and would encourage conversations, and the discussion strategy supported the proposed discussion questions. In addition, the instructor 
provided leaders with a ranking of their discussion questions from the most to least likely to encourage conversations.

\section{Instructor Reviewed}

Explained discussion strategies

Demonstrated how to use the strategies

\section{Posted Synopsis and Discussion Questions}
Created synopsis and reflection

Created discussion questions

\section{Instructor Reviewed}

Judged whether main ideas were covered
Provided feedback on discussion questions
Chose discussion facilitation strategy

\section{Facilitate Discussion}

Posted synopsis and discussion questions

Facilitated discussion using selected strategy and peer assessment

Figure 3.2. The process of student-led discussion and peer assessment.

\section{Discussion Facilitation}

Discussion leaders posted the synopsis with reflection and discussion questions at the beginning of the discussion week. The discussion started on Tuesdays (see Figure 3.2). Once the discussion began, the leader facilitated the discussion using the strategy chosen. Other participants (participants who were not leading discussion are called other participants) responded to the discussion question (called "original posts") by Thursdays. Leaders assessed their peers' original posts using a list containing the indicators of cognitive engagement to enhance other participants' cognitive engagement (see Appendix A). If an original post was too 
shallow and cognitive engagement was lacking, the leaders asked questions to encourage their peers to think more critically. For example, "practical application" is an indicator of cognitive engagement. If, according to the leaders' peer review, it was missing, then the leader posed such a question as, "how do you think this will apply to unethical behavior in the professional culture?" This question provided other participants an additional opportunity to think more deeply about the learning content and discussion question.

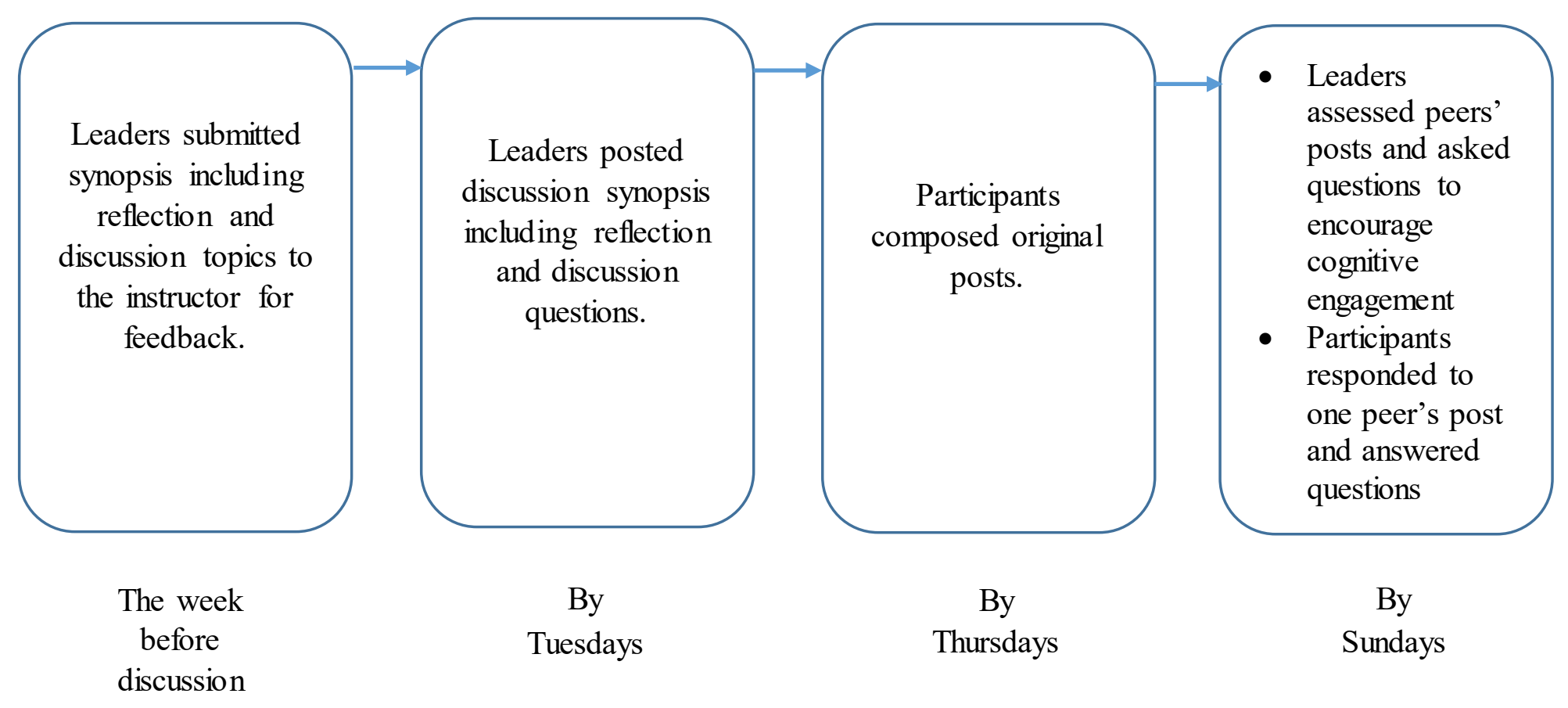

Figure 3.3. Timeline for student-led discussion.

\section{Measures}

\section{Behavioral Engagement}

Behavioral engagement was measured by counting the number of original posts and comments that were created each week. Additionally, interviews were conducted to obtain an indepth understanding of participants' behavioral engagement. Interview questions (see Appendix B) were derived from literature on engagement and online discussion. They were open-ended so 
that participants could fully communicate to the researchers their online discussion experience.

See Table 3.4 for a summary of the data collected for behavioral engagement.

\section{Cognitive Engagement}

Cognitive engagement was measured using the Motivated Strategy for Learning

Questionnaire (MSLQ) survey (Pintrich \& de Groot, 1990). The instrument was a self-report survey with thirteen seven-point Likert scale items that examined participants' cognitive strategy use. The questions were reworded to align with the context of this study. For example, this study used "When I create original posts and make comments on other students' posts, I try to put together the information from class and from the book" as opposed to "When I study for a test, I try to put together the information from class and from the book." See Table 3.3 for a sample survey item. The Cronbach's alpha reliability was .85. In addition to survey items, interviews were conducted and online discussion posts were collected to examine participants' cognitive engagement. See Table 3.4 for a summary of the data collected for cognitive engagement (instruments located in Appendix C).

Table 3.3

Instruments to Measure Cognitive and Emotional Engagement and a Sample Item of Each Instrument

\begin{tabular}{cll}
\hline \multicolumn{1}{c}{ Construct } & \multicolumn{1}{c}{ Instrument } & \multicolumn{1}{c}{ Sample item } \\
\hline Cognitive engagement & $\begin{array}{l}\text { Motivated Strategy for } \\
\text { Learning Questionnaire } \\
\text { (MSLQ) }\end{array}$ & $\begin{array}{l}\text { When reading online discussion } \\
\text { I try to connect the things I am } \\
\text { reading about with what I } \\
\text { already know. }\end{array}$ \\
Emotional engagement & $\begin{array}{l}\text { Achievement Emotions } \\
\text { Questionnaire (AEQ) }\end{array}$ & $\begin{array}{l}\text { I feel positive about the } \\
\text { discussion assignments I } \\
\text { complete in this class/course. }\end{array}$ \\
\hline
\end{tabular}




\section{Emotional Engagement}

Emotional engagement was assessed using a modified version of the Achievement Emotions Questionnaire (AEQ; (Pekrun, Goetz, Frenzel, Barchfeld, \& Perry, 2011). The instrument was tested in a study in a higher education context to assess students' emotions related to achievement (Pekrun et al, 2011). The instrument measured emotions including enjoyment, pride, anger, anxiety, shame, boredom, and hopelessness. All of the emotions except hopelessness were measured. Hopelessness was omitted because, first, it was an extreme emotion that is rare in this class, based on the judgement of the researcher who had taught this course for more than five years. Second, hopelessness is triggered when achievement seems uncontrollable (Pekrun et al, 2011). In this study participants were asked to provide opinionbased answers so even if they had little knowledge of the course content, achievement was within their control. The response format of the survey was a five-point Likert scale ranging from 1 (strongly disagree) to 5 (strongly agree). The Cronbach's alpha reliability for enjoyment was .80 , anxiety was .85 , shame was .83 , boredom was .81 , pride was .81 , and anger was .81 . In addition to survey items, interviews were conducted for an in-depth understanding of participants' emotional engagement. See Table 3.4 for the data collected for emotional engagement.

\section{Academic Performance}

Discussion leaders' academic performance included (a) the quality of the initial submission of the synopsis including reflection, discussion questions, and facilitation strategy selection, and (b) how well they facilitated online discussion. To assess their initial submission, a rubric created by the instructor was used (see Appendix D1). The rubric consisted of four criteria. One criterion helped to judge whether the synopsis included an overview of the weekly 
readings focusing on key elements and a reflection relating the concepts to their personal experience. Other criteria focused on the discussion questions created and the strategy that the leader chose. The quality of writing was an additional criterion to assure proper spelling, grammar, and punctuation. The leaders' facilitation was assessed separately by the criterion concerning the extent to which discussion facilitation enhanced the conversation and encouraged other participants' critical thinking (see Appendix D2).

Other participant's online discussion was evaluated by another rubric created by the instructor (see Appendix D3). The first criterion assessed participants' level of critical thinking and connection to the course content and readings. The next criterion dealt with the quality of writing to assure proper spelling, grammar, and punctuation were used. The final criterion assessed whether participants engaged with peers' original posts and shared comments in a way that created further discussion.

\section{Data Collection Procedure}

The pre-survey was administered before discussion started. At the conclusion of the fiveweek discussion period, participants were asked to complete the post-survey. The pre-survey for the $\mathrm{CG}$ and the EG consisted of the same survey items. The post-survey for the EG participants consisted of the same survey items as the CG post-survey, with additional items that assessed the EG participants' engagement in discussion facilitation. After participants completed the postsurvey, they were invited to a semi-structured interview. Sixteen participants, who were willing to share their online discussion experience, were interviewed. The original discussion posts and comments participants made on their peers' original posts, as well as their academic performance, were collected for analysis. 
Table 3.4

Data Collected and Data Analysis Method for the Dependent Variables

\begin{tabular}{|c|c|c|}
\hline Dependent variables & Data collected & Data analysis \\
\hline \multirow{2}{*}{$\begin{array}{l}\text { Behavioral } \\
\text { engagement }\end{array}$} & Interview & Theme identification \\
\hline & Online discussion posts & $t$-test \\
\hline \multirow{4}{*}{$\begin{array}{l}\text { Cognitive } \\
\text { engagement }\end{array}$} & Pre-survey & ANOVA \\
\hline & Post-survey & $\begin{array}{l}\text { Randomized block design ANOVA } \\
\text { ANOVA }\end{array}$ \\
\hline & Interview & Theme identification \\
\hline & Online discussion posts & Theme identification \\
\hline \multirow{4}{*}{$\begin{array}{l}\text { Emotional } \\
\text { engagement }\end{array}$} & Pre-survey & ANOVA \\
\hline & Post-survey & $\begin{array}{l}\text { Randomized block design ANOVA } \\
\text { ANOVA }\end{array}$ \\
\hline & Interview & Theme identification \\
\hline & Online discussion posts & Theme identification \\
\hline \multirow[t]{2}{*}{$\begin{array}{l}\text { Academic } \\
\text { performance }\end{array}$} & $\begin{array}{l}\text { Leaders' initial submission and } \\
\text { discussion facilitation }\end{array}$ & Descriptive analysis \\
\hline & Online discussion grades & $t$-test \\
\hline
\end{tabular}

\section{Data Analysis}

\section{Surveys}

A randomized block design ANOVA was conducted to examine whether the intervention had a different impact on the different blocks' cognitive and emotional engagement. Each discussion group was considered as a block. Five EG students were assigned to a discussion group before the study participants were recruited. Not all five students in each discussion group were willing to participate in the study. As a result, the blocks included different numbers of participants. The average number of participants in a block was 3.92, so each block was considered to have three participants. For the blocks that included more than three participants, the participants whose cognitive engagement or emotional engagement scores that were closest to the block mean were deleted. One group included only two participants, so the block mean 
was assigned to the third hypothetical participant. The result showed that there was no statistical difference among blocks.

A one-way ANOVA was used to compare the CG and the EG's pre-survey data to examine whether there was a difference in their engagement in online discussion before they participated in this study. The result showed that there was no statistically significant difference in the CG and the EG's engagement prior to participating in online discussion in this class. Therefore, a one-way ANOVA was used to compare the CG and all EG block's post-survey to examine whether there was a difference in their engagement in online discussion after the intervention.

\section{Interviews}

Interviews were transcribed verbatim. Pre-determined codes based on engagement and online discussion literature were used to analyze interviews. The data analysis method was deductive analysis (Braun \& Clarke, 2006). Data analysis followed the procedures suggested by (Ruona, 2005)): First, all identifiable information was removed from the transcripts to maintain anonymity. Second, transcripts were read by the researcher in order to gain familiarity with the data. Third, the interview data were coded using codes developed by the researcher. Finally, the meanings were generated from the results (Ruona, 2005).

For validity and reliability of interview analysis, the researcher and her advisor were involved in data analysis. The researcher developed the interview codes based on the engagement and online discussion literature. The researcher and her advisor then discussed the codes, reviewed three interview transcripts, and then had another discussion to refine the codes. They then analyzed three CG interviews independently using NVivo 12. Cohen's Kappa coefficient was .74. Discrepancies were discussed. After that, three EG interviews were analyzed 
by the researcher and her advisor independently. Cohen's Kappa coefficient was .83 . The researcher then analyzed the remaining interviews.

\section{Original Discussion Posts and Comments}

The number of original posts and comments each participant made each week was counted. An independent sample t-test was conducted to compare the CG's and the EG's number of original posts and comments.

Participants' discussion posts were analyzed using thematic analysis to examine their cognitive engagement. A pre-determined coding scheme was created based on cognitive engagement and online discussion literature. To be specific, the analysis focused on whether

participants connected the discussion to weekly course readings and other courses, and whether they used the knowledge they had gained in the ethics class. The subject matter expertise was needed for discussion post analys is. Therefore, the researcher, who was also the course instructor, was the only one who was able to conduct the analysis. The analysis was deductive and NVivo 12 was used.

\section{Academic Performance}

The CG and the EG participants' original discussion posts and comments were graded using a rubric (Appendix D3). The CG and each EG block's grades were compared using oneway ANOVA. The EG had a discussion facilitation grade that was unique to this group and a descriptive analys is of the grade was conducted. 


\section{Chapter IV}

\section{RESULTS}

\section{Behavioral engagement}

\section{Interviews.}

Both the CG and the EG participants reported that they all made original posts and one to two comments on peers' posts each week. They spent an average of approximately 25 minutes in composing the original discussion posts.

\section{Numbers of original discussion posts and comments.}

The CG participants posted .92 original posts every week and the EG participants posted .76 original posts (see Table 4.1). An independent sample $t$-test shows that there was no statistically significant difference in the average number of original posts per participant every week $(t=4.2, p=.21, r=.83)$ (see Table 4.1). The CG and the EG participants made an average of 1.06 and 1.48 comments every week, respectively. There was a statistically significant difference in the average number of comments per participant every week $(t=-2.1, p=.01, r=$ $.60)$.

Table 4.1

Average numbers of original discussion posts and comments per participant every week.

\begin{tabular}{|c|c|c|c|c|c|c|c|}
\hline & $\begin{array}{c}C G \\
(n=43)\end{array}$ & & $\begin{array}{c}\mathrm{EG} \\
(\mathrm{n}=47)\end{array}$ & & & & \\
\hline & $M$ & $S D$ & $M$ & $S D$ & $t$ & $p$ & $r$ \\
\hline $\begin{array}{l}\text { Average number of original } \\
\text { posts per participant }\end{array}$ & .92 & .07 & .76 & .04 & 4.2 & .21 & .83 \\
\hline $\begin{array}{l}\text { Average number of } \\
\text { comments per participant }\end{array}$ & 1.1 & .05 & 1.5 & .44 & -2.1 & $.01 *$ & .60 \\
\hline
\end{tabular}




\section{Cognitive engagement}

\section{Survey.}

A block design ANOVA was conducted to examine whether there was a difference in the impact of student-led discussion on each block. The result showed that there was no statistically significant difference. As shown in Appendix E, a one-way ANOVA showed that there was no statistically significant difference in the CG participants' and the EG blocks' cognitive engagement $(F(1,78)=1.02, p=0.4)$.

\section{Interviews.}

A thematic analysis of the interview revealed that both the CG and the EG participants were cognitively engaged in online discussion, which is suggested by the following two types of behaviors. First, the majority of the CG participants and seven out of seven blocks in the EG reported that they connected the discussion to course readings. For example, one CG participant stated: "I always try to cite from the readings on my posts." Similarly, an EG participant shared her weekly process:

I would read the modules, take a bit of notes, kind of gather the general ideas of the chapter or whatever, and then read the question just answer it based on what I thought was true outside of the readings and then tie it in with stuff that I learned from that week's lesson I guess.

Second, the majority of the CG participants and seven out of seven EG blocks made extra efforts to read their peers' comments on their own discussion posts, although they were not required to do so. When describing what she did after she posted her original post, one CG participant noted: "I go in and look at my post first and see what people have responded and then I go through and 
find other people's posts and comment on theirs. I almost always check what people put on mine first."

\section{Discussion posts.}

A thematic analysis of the original discussion posts and comments showed that the majority of the CG participants and seven out of seven EG blocks applied what they had learned in the class. In an original post, a CG participant related the course concept of the CSI Effect to her internship experience:

Although the idea behind the CSI effect seems to make sense to me, this summer I interned at my county's District Attorney's Office so I witnessed several trials and no one ever asked for more forensic evidence or seemed to think there wasn't enough. Which is why I am not surprised that there is currently no empirical research supporting the CSI effect (Roberts, para. 5).

An EG participant shared his application of course concepts to his undergraduate laboratory research, "I have a research job with Dr. Trejos. I try to pull what I know about how we work into how it fits into ethical practices and standards."

The EG participants demonstrated a higher level of cognitive engagement than their counterpart. The CG participants used many quotes from the readings to support their views, as required by the course instructor. For example, when discussing professional cultural differences, one participant quoted the instructor's textbook in his discussion post:

In the forensic and law enforcement communities, the police officers, forensic personnel, and lawyers may all have different rules that should be followed or different ideas and values that they relate with (Bowen, Ethics and the Practice of Forensic Science, Pages 127-128). For example, forensic analysts often find themselves performing the end work 
of what police officers and detectives may send to them. This end work requires a nonbias, ethical approach. The problem is that officer's minds normally lean toward a particular defendant being guilty. It is up to the individual working with people from various professions to learn the ethical standards within those professions and adapt to them.

The CG provided quotes from the textbook or the instructor's presentations to support their opinions. However, seven out of seven blocks of the EG participants utilized specific course concepts of culture and pressure to support their perspectives, thus demonstrating higher level of cognitive efforts than simply quoting the readings. One EG participant highlighted a positive aspect of the "us versus them" perspective within the law enforcement culture: "I think it could be beneficial for police officers to have an "us versus them" mindset because it builds shared values in the police force that at times can help officers survive their emotionally and difficult taxing job." Another EG participant discussed pressures applied to forensic professionals by law enforcement: 'It [pressure] may not be considered unethical in their [police officers'] department as they should bring justice ASAP. However, on the forensic aspect, this pressure to perform fast can result in missing information or false test results." This participant not only understood how the concept of pressure related to law enforcement, but was also able to apply the concept to the "bigger picture" of the impact of law enforcement on the forensic scientists and society.

\section{Emotional engagement}

\section{Survey.}

A block design ANOVA was conducted to examine whether there was a difference in the impact of student-led discussion on each block. The result showed that there was no statistically significant difference. As shown in Appendix E, a one-way ANOVA indicated that there was no 
statistically significant difference in the CG and the EG participants' emotional engagement, including enjoyment, pride, anger, anxiety, shame, and boredom.

The post-survey included questions that were specifically related to the EG participants' emotional reactions to discussion facilitation (see Table 4.2). Descriptive statistics showed the average scores for enjoying leading online discussion $(M=3.51, S D=1.20)$, their perception of whether the discussion went well $(M=3.77, S D=.94)$, whether they enjoyed leading and participating in the student-led discussion $(M=3.23, S D=1.20)$, their emotional reaction to student-led discussion $(M=4.00, S D=1.0)$, and their anxiety related to student-led discussion $(M=3.87, S D=1.15)$. The values related to their emotional reaction and anxiety had higher means. Histograms of participants' responses to emotional reaction questions show that the data are not normally distributed or bimodal (see Figure 4.1). The Cronbach's alpha reliability was .78

Table 4.2

EG student-led discussion survey questions.

\begin{tabular}{lll}
\hline EG $(\mathrm{n}=47)$ & $M$ & $S D$ \\
\hline I enjoyed leading online discussion. & 3.51 & 1.20 \\
I think that student-led online discussion went great. & 3.77 & .94 \\
$\begin{array}{l}\text { I enjoyed leading online discussion and also participating } \\
\text { in the discussion led by other groups so much that I was }\end{array}$ & 3.23 & 1.20 \\
$\begin{array}{l}\text { strongly motivated to work on these tasks. } \\
\begin{array}{l}\text { I was annoyed that the instructor was not leading } \\
\text { discussion. }\end{array}\end{array}$ \\
$\begin{array}{l}\text { I was so anxious that I couldn't fully concentrate on my } \\
\text { student-led discussion posts. }\end{array}$ & 3.00 & 1.00 \\
\hline
\end{tabular}
Possible range of emotional engagement: 1-5 

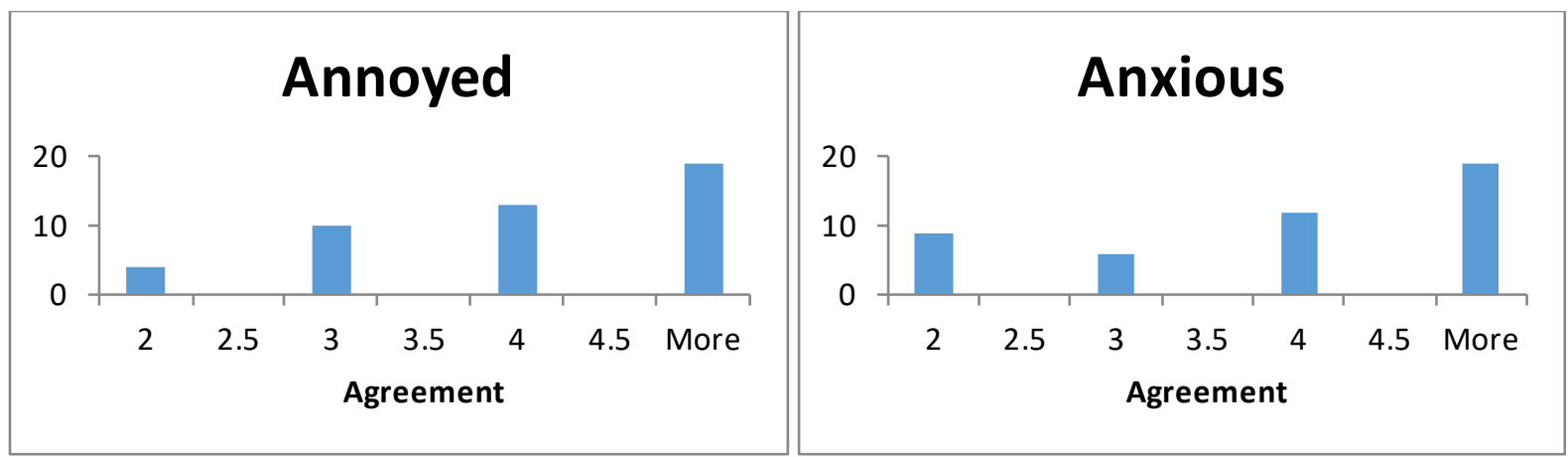

Figure 4.1. Histograms of highly emotional responses.

\section{Interviews.}

The majority of the CG participants and seven out of the seven EG blocks reported a high level of emotional engagement, evidenced by the value they associated with the online discussion, as well as how they liked the structure of the discussion. One CG participant commented on her perceived value of online discussion: "I guess, essentially, communicate ideas and see if students are actually comprehending the material, instead of just, like, clicking through and just taking quizzes." An EG participant articulated the value of online discussion as follows:

It just helps you engage with others and it gives other standpoints and views on how things are, other than outside of just lecture learning. I think it helps you learn better 'cause (sic) you're actually engaging with somebody else on something, rather than just reading a reading or things of that nature.

Both groups liked online discussion because of the way online discussion was organized and managed in the class. One CG participant said, "And I kind of liked the consistency of them, so like, first part due Thursday, second part due Sunday. So then I don't have to keep scrambling and checking the syllabus and be like, which one's which?" While an EG participant stated, "I think it's managed pretty well. From previous online classes, I think this is probably one of the more organized ones.” 
In particular, the six out of seven blocks of the EG participants liked student-led discussion. They shared that this type of discussion motivated them to put forth more effort than when they were a discussion participant, as one participant shared, "I think it kind of makes you have to kind of put in an effort to grasp what's being discussed." They also liked the various facilitation strategies used by different leaders, "I like how there's the devil's advocate and then role playing." The EG participants could relate to their peers better than the instructor. As one participant stated:

I feel like it [student-led discussion] is different just being able to discuss with your peers compared to a professor. Not intimidating but I feel like there's more room for conversation, where the one week someone asked about how we felt about underage drinking, and I feel like it's a lot easier to relate to someone of my peers.

The EG participants were also asked about how they felt about assessing their group members' original posts using a list of cognitive engagement indicators. They thought the list was helpful, as one participant stated, "And it [the list] kept me on track, kind of gave me an outline on what to do." The list also guided participants to compose comments on their peers' posts in the weeks when they were not leaders. One participant stated that "I definitely found it helpful because the first discussion week I kind of just commented on other people's responses, instead of trying to build upon it. So those questions really helped, not only as the leader but as a participant."

The EG participants were asked to informally evaluate the leaders' facilitation during the interview. Most participants thought the leaders' facilitation met their expectations. For example, one student found the group leaders did a good job: 'Yeah, there was never a time, I don't think, 
where I was like oh, they're not really doing their job as the group leader." Yet, another participant shared constructive criticism by saying:

I think that there was some that honestly weren't clear on what they wanted for their facilitation because I remember very clearly at least one of them, I just answered the question, because there was no facilitation... But for the ones that were very apparent in how they wanted us to participate I think they did a very good job. It was very easy to do whatever they asked.

\section{Academic performance}

The CG and the EG participants' academic performance included their discussion grades and the EG participants' discussion facilitation grades. An independent sample t-test was conducted to compare the CG and the EG participants' discussion grades. As shown in Table 4.3, there was no statistically significant difference between the CG and the EG's discussion $1(t=-$ $.15, p=.28, r=-.02)$, Discussion $2(t=1.3, p=.08, r=.15)$, Discussion $3(t=1.4, p=.13, r=$ $.16)$, Discussion $4(t=1.2, p=.07, r=.14)$, and Discussion $5(t=.06, p=.62, r=0)$. A descriptive analys is of the EG discussion leaders' facilitation grades was conducted. The results of the discussion facilitation grades are shown in Table 4.4. The average grade of the EG discussion leaders' initial submission of the synopsis including reflection, discussion questions, and the selection of discussion facilitation strategy was 18.80 out of 25 . Their discussion facilitation was 16.20 out of 20 . 
Table 4.3

Average grades of the $\mathrm{CG}$ and the EG participants per discussion.

\begin{tabular}{|c|c|c|c|c|c|c|c|}
\hline & $\begin{array}{c}\mathrm{CG} \\
(\mathrm{n}=43) \\
M\end{array}$ & $S D$ & $\begin{array}{c}\begin{array}{c}\mathrm{EG} \\
(\mathrm{n}=47)\end{array} \\
M\end{array}$ & $S D$ & $t$ & $p$ & $r$ \\
\hline Discussion 1 & 11.72 & 3.78 & 11.90 & 5.22 & -.15 & .28 & -.02 \\
\hline Discussion 2 & 13.04 & 3.76 & 11.71 & 4.52 & 1.26 & .08 & .15 \\
\hline Discussion 3 & 13.64 & 2.70 & 12.58 & 3.35 & 1.38 & .13 & .16 \\
\hline Discussion 4 & 14.14 & 1.75 & 13.37 & 3.04 & 1.20 & .07 & .14 \\
\hline Discussion 5 & 13.69 & 2.39 & 13.65 & 2.88 & .06 & .62 & 0 \\
\hline
\end{tabular}

$* p<0.05$

Possible range of participants' discussion grades: $0-15$

Table 4.4

Discussion leaders' facilitation grades.

\begin{tabular}{ccc}
\hline $\begin{array}{c}\text { EG } \\
(\mathrm{n}=47)\end{array}$ & $M$ & $S D$ \\
\hline Initial submission ${ }^{\mathrm{a}}$ & 18.80 & 6.03 \\
Discussion facilitation ${ }^{\mathrm{b}}$ & 16.20 & 6.26 \\
\hline a: Possible range of initial submission: & $0-25$ \\
b: Possible range of leader facilitation: & $0-20$
\end{tabular}




\section{Chapter V}

\section{DISCUSSION}

\section{Summary of Findings}

The impact of student-led discussion on student engagement in online discussion was examined. Both the CG and the EG students were behaviorally engaged in online discussion as demonstrated by the numbers of their original posts and comments on their peers' posts. The EG students posted a higher number of comments than the CG students. There was not a statistically significant difference in cognitive engagement between the CG and the EG students. Interview and discussion post analyses suggest that students in both groups connected their online discussion to the course readings, made extra efforts to read peer's comments on their discussion, and applied the knowledge they gained in the class to personal experiences, such as internships. The main difference in cognitive engagement between the CG and the EG was the way in which knowledge application occurred; the CG students quoted readings to support their opinions whereas the EG students applied the core ideas of the class to real life situations. There was not a statistically significant difference in emotional engagement between the two groups. Interview data suggest that both groups valued online discussion and both liked how it was organized. The EG students liked the student-led format, however, most students preferred participating in the student-led online discussion rather than leading. The findings are discussed in detail in this chapter.

\section{RQ1: To what extent and in what ways did student-led discussion affect undergraduate student engagement in online discus sion?}

Both the CG and the EG were behaviorally engaged in the online discussion as shown by the number of original posts and comments on their peers' posts. As shown in Table 4.1, almost 
every CG student made an original post $(M=0.92, S D=0.07)$. The majority of the EG students composed an original post $(M=0.76, S D=0.04)$. This is contrary to prior studies that show that some students did not post in the discussion forum as required (Levine, 2007). One possible reason for the behavioral engagement in online discussion in this study could be contributed to the organization of online discussion. Both the CG and the EG students reported in the interviews that they liked how the online discussion was managed. The deadlines of original posts and comments, consistent throughout the five discussion weeks, were described in the course syllabus and also listed in the learning management system. This made the instructors' expectations and requirements clear, which led to students' behavioral engagement (Connell, 1990).

The EG students demonstrated a higher level of behavioral engagement than the CG students, evidenced by the additional comments the EG students made. One possible reason for why the EG students made more comments is that discussion leaders asked questions if they thought their peers' posts did not reflect deep thinking. Students who were not leading the discussion were encouraged to respond to the leader's questions and comments. Most of the EG students responded to the leaders' questions.

Students in both the CG and the EG's demonstrated a high level of cognitive engagement. Both groups reported in the interview that they connected their discussion to the course readings. An analysis of the discussion posts showed that the CG students quoted the weekly readings to support their opinions and the EG students used fundamental concepts when they related the learning content to their personal experiences such as internships and research papers. The discussion posts and interview data suggest a high level of cognitive engagement as when students make connections between different ideas, they were cognitively engaged in the 
learning materials (Fredricks et al., 2004). In addition, both groups said they made extra efforts to read their peers' comments on their own discussion posts. Going beyond requirements and showing investment through extra effort also suggests a high level of cognitive engagement (Fredricks et al., 2004; Newmann, Wehlage, \& Lamborn, 1992).

The EG students seemed to experience a higher level of cognitive engagement than did the CG students. The majority of the CG students simply cited course materials in their original posts to support their views as they were required to do, whereas the EG students demonstrated their application of course concepts to their experiences and had a higher level of investment with the course content. One reason why the EG students applied the core course concepts is that the synopsis including a reflection may have helped them focus on the main ideas. Another possible reason could be the peer pressure of being part of a small group. All the CG students posted in one online discussion board. However, the EG students participated in small group discussion on a self-contained discussion board. They knew that it was difficult to avoid peers judging those who might not have done the readings or grasped the concepts. Also, the EG students knew that their leaders exerted efforts in creating a synopsis with a reflection for weekly readings. They may have wanted to reciprocate effort they received, or hoped to receive, when it was their turn to lead. Another way the EG students demonstrated a higher level of cognitive engagement was through taking notes while reading articles and creating their synopsis and reflection. Note taking is a deep learning strategy that requires students to comprehend, evaluate, and organize information simultaneously. It is an effective strategy which leads to learning (Reed, Rimel, \& Hallett, 2016).

In terms of emotional engagement, students in both the CG and the EG groups liked online discussion because of the structure of the discussion. Classroom structure, established 
through teachers' clear expectations and consistent responses, leads to students' positive attitude (Connell, 1990; E. A. Skinner \& Belmont, 1993). Another reason why both groups liked online discussion was the opportunity to apply what they had learned. In particular, the EG leaders shared that they had an additional opportunity for knowledge application by creating discussion questions for their peers. An additional reason why the EG students liked the discussion is social congruence. Some EG students mentioned that they were of equal social status with the leaders which suggests that a social congruence was created when the online discussion took place, which means that a social congruence was created during online discussion. Social congruence leads to positive emotions (Newcombe \& Ashkanasy, 2002).

The EG students liked facilitating online discussion because, as they reported in the interview, they could critically think about the content of the course readings, create their own discussion questions, and guide the discussion direction. This means that, in their point of view, facilitating online discussion contributed to their own learning and helped their peers with knowledge construction. This is in line with prior studies in which students reported that they liked the ownership of the direction of the discussion (Hew, 2015) and student-led online discussion enhanced students' knowledge construction (De Wever et al, 2010).

Although the EG students stated, during the interview, that they liked facilitating online discussion, they preferred participating in discussion to leading online discussion. This is in line with the survey result that shows, to some extent, students enjoyed online discussion, but they did not enjoy it very much (the mean of the enjoyment of online discussion being 3.51 out of 5). The reasons they shared during the interview include the increased amount of responsibility, the pressure to inform their peers, and decreased ability to safeguard against demonstrating a lack of understanding of the content. The survey result also shows that they were annoyed that their 
instructor was not leading online discussion (the mean of being annoyed being 4.00 out of 5) and they were anxious when leading discussion (the mean of being annoyed being 3.87 out of 5). Although the underlying cause is unknown, it is possible that the negative wording may have confused the students as to the meaning of the 1-5 scale. The finding is in line with prior studies show that students think it is the instructors' responsibility to facilitate online discussion (Dröge \& Spreng, 1996) and they experience anxiety when leading online discussion (Hew, 2015). Another study (Hew, 2015) also found that students only preferred peer facilitation when they wanted freedom in sharing their views, ownership in directing the discussion, and when the students wanted to experience the leadership role.

\section{RQ2: To what degree did student-led discussion impact undergraduate students' academic performance?}

There was no statistically significant difference between the CG and the EG students' academic performance. However, the analysis of students' original posts show that the EG students applied the core course concepts to their discussion, whereas the CG students simply quoted the course readings to support their points of view. This shows that the EG students' original posts were of higher quality. The reason for this discrepancy between the quantitative (online discussion grades) and qualitative (discussion posts) results can be attributed to the rubric used to assess participant's original posts. The rubric focused on the level of cognitive engagement, the level of connecting to the course content, and the quality of writing. The rubrics were aligned with literature that suggests that academic performance in online discussion can be measured by the number of responses, speed of responses, and/or type of response (Harmon, Alpert, \& Histen, 2014). A deep examination of the rubric showed that it did not seem to capture the nuances of cognitive engagement, suggested by the description of excellent content: "Posts 
show an excellent understanding of the content. Additional resources and specific examples are cited and integrated to support main ideas. Opinions are clear."

\section{RQ3: How did peer assessment impact undergraduate student engagement in} asynchronous online discussion?

Students reported that the list of cognitive engagement indicators provided by the instructor guided the leaders. In addition, the list guided the students as they commented on their peers' posts. This suggests that the list was instrumental in knowledge construction in the online discussion forum. This also shows that peer assessment not only encouraged the EG leaders to support their peers to improve their original posts and comments, but it also helped leaders become more confident in online discussion as participants. This is in line with the findings of prior studies showing that peer feedback is valuable and reinforced learning while creating more posts (Ertmer et al., 2007) and it made students more comfortable and confident with original posts and responses (Ertmer et al., 2010).

\section{Research Limitations and Future Research Directions}

There are several limitations in this study. First, the participants were undergraduate students representing a variety of programs and having varying degrees of experience with online courses. Given the subject matter, an additional study conducted of only Forensic and Investigative Science majors may impact the outcome.

The second limitation pertains to the number of participants in each block. The EG students were from two sections of the forensic science course in one semester. Students in these two sections worked in groups of five for online discussion. Each discussion group was considered a block. The researcher randomly assigned students to discussion groups at the beginning of the semester. However, not all five students in each discussion group participated in 
the study. In addition, some students who agreed to participate did not complete the pre-survey or post-survey, so their data were not used. As a result, the blocks included a different number of participants. However, in a randomized block design study, all blocks should have an equal number of participants.

Third, due to the breadth of the study, the impact of peer assessment was not examined to a higher extent. Future studies can conduct an in-depth examination of the impact of peer assessment on student-led discussion by asking students to reflect on how peer assessment helped or had a negative influence on student-led discussion.

Finally, the Learning Management System cannot track how many times students viewed the discussion page, how long they stayed on the page, and the number of responses they provided. These data may enable the researchers to better understand students' behavioral engagement. It would be valuable to locate or design a tool to track such data.

\section{Conclusion}

This study was designed to enhance student engagement in asynchronous online discussion. Based on the literature regarding student engagement, student-led discussion, discussion facilitation strategies, social and cognitive congruence, a student-led asynchronous online discussion was designed. The study examined the effects of student-led discussion on student engagement and academic performance. The results showed that there was no statistically significant difference in the CG and the EG students' cognitive and emotional engagement, and academic performance. The EG students posted a significantly higher number of comments than the CG students. An analysis of the interview and discussion posts suggests that both the CG and the EG were highly engaged in online discussion. Peer assessment was reported to be helpful in encouraging student leaders to ask follow-up questions. This study 
presents a design of student-led discussion that strived to enhance engagement in asynchronous online discussion. This study, despite several limitations, provides directions for future research on student engagement in online discussion. 


\section{References}

Allen, I. E., \& Seaman, J. (2013). Changing course: Ten years of tracking online education in the United States. Retrieved from Pearson website: https://eric.ed.gov/? id=ED541571

Angelino, L., Williams, F., \& Natvig, D. (2007). Strategies to engage online students and reduce attrition rates. Journal of Educators Online, 4(2).

Asterhan, C.S. C., \& Eisenmann, T. (2011). Introducing synchronous e-discussion tools in colocated classrooms: A study on the experiences of 'active' and 'silent' secondary school students. Computers in Human Behavior, 27(6), 2169-2177.

Axelson, R. D., \& Flick, A. (2011). Defining student engagement. Change: The Magazine of Higher Learning, 43(1), 38-43.

Baran, E., \& Correia, A.-P. (2009). Student-led facilitation strategies in online discussions. Distance Education, 30(3), 339-361.

Bawa, P. (2016). Retention in online courses: Exploring issues and solutions-A literature review. SAGE Open, 6(1). https://doi.org/10.1177/2158244015621777

Boud, D. (1995). Enhancing learning through self-assessment. Routledge.

Braun, V., \& Clarke, V. (2006). Using thematic analysis in psychology. Qualitative Research in Psychology, 3(2), 77-101.

Buckley, F. (2011). Online discussion forums. European Political Science, 10, 402-415.

Carr, S. (2000). As distance education comes of age, the challenge is keeping the students. Chronicle of Higher Education, 46(23), A39-A41.

Chan, J. C. C., Hew, K. F., \& Cheung, W. S. (2009). Asynchronous online discussion thread development: Examining growth patterns and peer-facilitation techniques. Journal of 
Computer Assisted Learning, 25(5), 438-452. https://doi.org/10.1111/j.13652729.2009.00321.x

Chen, B., Chang, Y.-H., Ouyang, F., \& Zhou, W. (2018). Fostering student engagement in online discussion through social learning analytics. The Internet and Higher Education, 37, 2130.

Cheung, W. S., \& Hew, K. F. (2010). Examining facilitators' habits of mind in an asynchronous online discussion environment: A two cases study. Australasian Journal of Educational Technology, 26(1), 123-132.

Christenson, S., Reschly, A. L., \& Wylie, C. (2012). Handbook of research on student engagement. (Vols. 1-1 online resource). Retrieved from http://site. ebrary.com/id/10537679

Cochran, J. D., Campbell, S. M., Baker, H. M., \& Leeds, E. M. (2014). The role of student characteristics in predicting retention in online courses. Research in Higher Education, $55(1), 27-48$.

Connell, J. P. (1990). Context, self, and action: A motivational analysis of self-system processes across the life span. In The self in transition: Infancy to childhood. (pp. 61-97). Chicago, IL, US: University of Chicago Press.

Cornelius, S., Gordon, C., \& Harris, M. (2011). Role engagement and anonymity in synchronous online role play. International Review of Research in Open \& Distance Learning, 12(5), 57-73. Retrieved from ehh.

Cornwall, M. (1979). Students as teachers: Peer teaching in higher education. Centrum Voor Onderoek van Wetenshappelijk Ouderwijs, University of Amsterdam. 
Creswell, J. W., \& Clark, V. L. P. (2007). Designing and conducting mixed methods research. Sage Publications.

Dabbagh, N., \& Kitsantas, A. (2005). Using web-based pedagogical tools as scaffolds for selfregulated learning. Instructional Science, 33(5), 513-540. https://doi.org/10.1007/s11251-005-1278-3

De Wever, B., Keer, H. V., Schellens, T., \& Valcke, M. (2010). Roles as a structuring tool in online discussion groups: The differential impact of different roles on social knowledge construction. Computers in Human Behavior, 26(4), 516-523.

https://doi.org/10.1016/j.chb.2009.08.008

Dennen, V. P. (2008). Pedagogical lurking: Student engagement in non-posting discussion behavior. Computers in Human Behavior, 24(4), 1624-1633.

Ding, L., Kim, C., \& Orey, M. (2017). Studies of student engagement in gamified online discussions. Computers \& Education, 115, 126-142.

Dixon, C. S. (2014). The three E's of online discussion. Quarterly Review of Distance Education, 15(1), 1-8.

Dixson, M. (2010). Creating effective student engagement in online courses: What do students find engaging? Journal of The Scholarship of Teaching \& Learning, 10(2), 1-13.

Domínguez, A., Saenz-de-Navarrete, J., de-Marcos, L., Fernández-Sanz, L., Pagés, C., \& Martínez-Herráiz, J.-J. (2013). Gamifying learning experiences: Practical implications and outcomes. Computers \& Education, 63, 380-392. https://doi.org/10.1016/j.compedu.2012.12.020 
Dröge, C., \& Spreng, R. (1996). Enhancing involvement and skills with a student-led method of case analysis. Journal of Marketing Education, 18(3), 25-34. https://doi.org/10.1177/027347539601800304

Duran, N. D., \& Fusaroli, R. (2017). Conversing with a devil's advocate: Interpersonal coordination in deception and disagreement. PLOS ONE, 12(6), e0178140. https://doi.org/10.1371/journal.pone.0178140

Ertmer, P. A., Richardson, J. C., Belland, B., Camin, D., Connolly, P., Coulthard, G., ... Mong, C. (2007). Using peer feedback to enhance the quality of student online postings: An exploratory study. Journal of Computer-Mediated Communication, 12(2), 412-433. https://doi.org/10.1111/j.1083-6101.2007.00331.x

Ertmer, P. A., Richardson, J. C., Lehman, J., Newby, T., Cheng, X., Mong, C., \& Sadaf, A. (2010). Peer feedback in online discussions: Impact on self-regulation (p. 35). West Lafayette, IN: Purdue University.

Forte, G., Schwandt, D., Swayze, S., Butler, J., \& Ashcraft, M. (2016). Distance education in the U.S.: A paradox. The Turkish Online Journal of Distance Education, 17(3), 16-30.

Fredricks, J. A., Blumenfeld, P. C., \& Paris, A. H. (2004). School engagement: Potential of the concept, state of the evidence. Review of Educational Research, 74(1), 59-109.

Fredricks, J. A., \& McColskey, W. (2012). The measurement of student engagement: A comparative analysis of various methods and student self-report instruments. In S. L. Christenson, A. L. Reschly, \& C. Wylie (Eds.), Handbook of research on student engagement (pp. 763-782). https://doi.org/10.1007/978-1-4614-2018-7_37 
Gao, F., Zhang, T., \& Franklin, T. (2013). Designing asynchronous online discussion environments: Recent progress and possible future directions. British Journal of Educational Technology, 44(3), 469-483.

Goehle, G. (2013). Gamification and web-based homework. PRIMUS, 23(3), 234-246.

Hammond, M. (2017). Online collaboration and cooperation: The recurring importance of evidence, rationale and viability. Education and Information Technologies, 22(3), 10051024. https://doi.org/10.1007/s10639-016-9469-x

Harmon, O. R., Alpert, W. T., \& Histen, J. (2014). Online discussion and learning outcomes. International Advances in Economic Research, 20(1), 33-44. https://doi.org/10.1007/s11294-013-9453-9

Hew, K. F. (2015). Student perceptions of peer versus instructor facilitation of asynchronous online discussions: Further findings from three cases. Instructional Science: An International Journal of the Learning Sciences, 43(1), 19-38. https://doi.org/10.1007/s11251-014-9329-2

Hew, K. F., \& Cheung, W. (2011). Higher-level knowledge construction in asynchronous online discussions: An analysis of group size, duration of online discussion, and student facilitation techniques. (Vol. 39). https://doi.org/10.1007/s11251-010-9129-2

Hew, K. F., \& Cheung, W. S. (2003). Evaluating the participation and quality of thinking of preservice teachers in an asynchronous online discussion environment: Part II. International Journal of Instructional Media, 30(Part 4), 355-366.

Hew, K. F., Cheung, W. S., \& Ng, C.S. L. (2010). Student contribution in asynchronous online discussion: A review of the research and empirical exploration. Instructional Science, $38(6), 571-606$. 
Hou, H.-T., \& Wu, S.-Y. (2011). Analyzing the social knowledge construction behavioral patterns of an online synchronous collaborative discussion instructional activity using an instant messaging tool: A case study. Computers \& Education, 57(2), 1459-1468. https://doi.org/10.1016/j.compedu.2011.02.012

Ilgaz, H., \& Gülbahar, Y. (2015). A snapshot of online learners: E-readiness, e-satisfaction and expectations. International Review of Research in Open and Distance Learning, 16(2).

Ioannou, A., Demetriou, S., \& Mama, M. (2014). Exploring factors influencing collaborative knowledge construction in online discussions: student facilitation and quality of initial postings. American Journal of Distance Education, 28(3), 183-195. https://doi.org/10.1080/08923647.2014.926780

Jaggars, S. S., \& Xu, D. (2016). How do online course design features influence student performance? Computers \& Education, 95, 270-284. https://doi.org/10.1016/j.compedu.2016.01.014

Kahn, P., Everington, L., Kelm, K., Reid, I., \& Watkins, F. (2017). Understanding student engagement in online learning environments: The role of reflexivity. Educational Technology Research and Development, 65(1), 203-218. https://doi.org/10.1007/s11423016-9484-z

Kulkarni, C., Wei, K. P., Le, H., Chia, D., Papadopoulos, K., Cheng, J., ... Klemmer, S. (2013). Peer and self-assessment in massive online classes. ACMTransactions on ComputerHuman Interaction, 20(6), 31. https://doi.org/10.1145/2505057

Kurnaz, F. B., Ergün, E., \& Ilgaz, H. (2018). Participation in online discussion environments: Is it really effective? Education and Information Technologies, 23(4), 1719-1736. 
Lee, E., \& Hannafin, M. J. (2016). A design framework for enhancing engagement in studentcentered learning: own it, learn it, and share it. Educational Technology Research and Development, 64(4), 707-734. https://doi.org/10.1007/s11423-015-9422-5

Lee, E., Pate, J., \& Cozart, D. (2015). Autonomy support for online students. TechTrends, 59(4), 54-61. https://doi.org/10.1007/s11528-015-0871-9

Lee, J.-M. (2006). Different types of human interaction in online discussion: An examination of using online discussion forum. Proceedings of the American Society for Information Science and Technology, 43(1), 1-11.

Levine, S. J. (2007). The online discussion board. New Directions for Adult and Continuing Education, 2007(113), 67-74.

Lineweaver, T. (2010). Online discussion assignments improve students' class preparation. Teaching of Psychology, 37(3), 204-209.

Lockspeiser, T. M., O’Sullivan, P., Teherani, A., \& Muller, J. (2008). Understanding the experience of being taught by peers: The value of social and cognitive congruence. Advances in Health Sciences Education, 13(3), 361-372. https://doi.org/10.1007/s10459006-9049-8

Lundberg, C. A., \& Sheridan, D. (2015). Benefits of engagement with peers, faculty, and diversity for online learners. College Teaching, 63(1), 8-15. Retrieved from ehh. Marchand, G. C., \& Gutierrez, A. P. (2012). The role of emotion in the learning process: Comparisons between online and face-to-face learning settings. The Internet and Higher Education, 15(3), 150-160.

Mayadas, A. F., Bourne, J., \& Bacsich, P. (2009). Online education today. Science, 323(2), 8589. 
McCrory, R., Putnam, R., \& Jansen, A. (2008). Interaction in online courses for teacher education: Subject matter and pedagogy. Journal of Technology and Teacher Education, $16(2)$.

Meyer, K. A. (2014). Student engagement in online learning: What works and why. $A S H E$ Higher Education Report, 40(6), 1-114. https://doi.org/10.1002/aehe.20018

Moody, J. (2004). Distance education: Why are the attrition rates so high? Quarterly Review of Distance Education, 5(3), 205-210.

Moore, F. (2017). Peer-led small groups: Are we on the right track? Perspectives on Medical Education, 6(5), 325-330. https:/doi.org/10.1007/s40037-017-0370-0

Moore, G. E., Warner, W. J., \& Jones, D. W. W. (2016). Student-to-student interaction in distance education classes: What do graduate students want? Journal of Agricultural Education, 57(2), 1-13.

Moore, R. L. (2014). Importance of developing community in distance education courses. TechTrends, 58(2), 20-24.

Murphy, E., \& Coleman, E. (2004). Graduate students' experiences of challenges in online asynchronous discussions. Canadian Journal of Learning and Technology, 30(2).

Nandi, D., Hamilton, M., \& Harland, J. (2012) Evaluating the quality of interaction in asynchronous discussion forums in fully online courses. Distance Education, 33(1), 5-30.

Newcombe, M. J., \& Ashkanasy, N. M. (2002). The role of affect and affective congruence in perceptions of leaders: an experimental study. Emotions and Leadership, 13(5), 601-614. https://doi.org/10.1016/S1048-9843(02)00146-7 
Newmann, F., Wehlage, G. G., \& Lamborn, S. D. (1992). The significance and sources of student engagement. In F. Newmann (Ed.), Student engagement and achievement in American secondary schools (pp. 11-39). New York: Teachers College Press.

Ng, C. S. L., Cheung, W. S., \& Hew, K. F. (2012). Interaction in asynchronous discussion forums: peer facilitation techniques. Journal of Computer Assisted Learning, 28(3), 280294.

Nguyen, V. A. (2017). A peer assessment approach to project based blended learning course in a Vietnamese higher education. Education and Information Technologies: The Official Journal of the IFIP Technical Committee on Education, 22(5), 2141-2157. https://doi.org/10.1007/s10639-016-9539-0

Parsons, S. A., Nuland, L. R., \& Parsons, A. W. (2014). The ABCs of student engagement. Phi Delta Kappan, 95(8), 23-27.

Pekrun, R., Goetz, T., Frenzel, A. C., Barchfeld, P., \& Perry, R. P. (2011). Measuring emotions in students' learning and performance: The Achievement Emotions Questionnaire (AEQ). Contemporary Educational Psychology, 36(1), 36-48.

Picciano, A. G. (2002). Beyond student perceptions: Issues of interaction, presence, and performance in an online course. Journal of Asynchronous Learning Networks, 6(1), 2140.

Pickering, J. D. (2017). Cognitive engagement: A more reliable proxy for learning? Medical Science Educator, 27(4), 821-823. https://doi.org/10.1007/s40670-017-0447-8

Pilkington, R. M., \& Walker, S. A. (2003). Facilitating debate in networked learning: Reflecting on online synchronous discussion in higher education. Instructional Science, 31(1-2), $41-63$. 
Pintrich, P. R., \& de Groot, E. V. (1990). Motivational and self-regulated learning components of classroom academic performance. Journal of Educational Psychology, 82(1), 33-40.

Plano Clark, V., \& Creswell, J. (2008). The Mixed Methods Reader. Sage. Thousand Oaks, California.

Reed, D. K., Rimel, H., \& Hallett, A. (2016). Note-Taking Interventions for College Students: A Synthesis and Meta-Analysis of the Literature. Journal of Research on Educational Effectiveness, 9(3), 307-333.

Reese, S. A. (2015). Online learning environments in higher education: Connectivism vs. dissociation. Education and Information Technologies : The Official Journal of the IFIP Technical Committee on Education, 20(3), 579-588.

Ruona, W. (2005). Analyzing qualitative data. In R. Swanson \& E. Holton (Eds.), Research in organizations: Foundations and methods of inquiry (pp. 223-263). San Francisco, CA: Berrett- Koehler.

Sadaf, A., \& Olesova, L. (2017). Enhancing cognitive presence in online case discussions with questions based on the practical inquiry model. American Journal of Distance Education, 31(1), 56-69. https://doi.org/10.1080/08923647.2017.1267525

Salter, N. P., \& Conneely, M. R. (2015a). Structured and unstructured discussion forums as tools for student engagement. Computers in Human Behavior, 46, 18-25.

Salter, N. P., \& Conneely, M. R. (2015b). Structured and unstructured discussion forums as tools for student engagement. Computers in Human Behavior, 46, 18-25.

Schlenker, B. R., Schlenker, P. A., \& Schlenker, K. A. (2013). Antecedents of academic engagement and the implications for college grades. Learning and Individual Differences, $27,75-81$. 
Schmidt, H., \& Moust, J. (1995). What makes a tutor effective? A structural equations modelling approach to learning in problem-based curricula. Academic Medicine, 70(8), 708-714.

Seaman, J., Allen, I. E., \& Seaman, J. (2018). Grade increase; Tracking distance education in the United States. (p. 49) [Research]. Babson Survey Research Group.

Shea, P., Sau Li, C., \& Pickett, A. (2006). A study of teaching presence and student sense of learning community in fully online and web-enhanced college courses. The Internet and Higher Education, 9(3), 175-190. https://doi.org/10.1016/j.iheduc.2006.06.005

Shieh, G., \& Show-Li, J. (2004). The effectiveness of randomized complete block design. Statistica Neerlandica, 58(1), 111-124. https://doi.org/10.1046/j.00390402.2003.00109.x

Sierens, E., Vansteenkiste, M., Goossens, L., Soenens, B., \& Dochy, F. (2009). The synergistic relationship of perceived autonomy support and structure in the prediction of selfregulated learning. British Journal of Educational Psychology, 79(1), 57-68.

Skinner, E. A., \& Belmont, M. J. (1993). Motivation in the Classroom: Reciprocal Effects of Teacher Behavior and Student Engagement Across the School Year. Journal of Educational Psychology, 85(4), 571.

Skinner, E., Furrer, C., Marchand, G., \& Kindermann, T. (2008). Engagement and disaffection in the classroom: Part of a larger motivational dynamic? Journal of Educational Psychology, 100(4), 765-781.

Tripathi, K., \& Dewan, A. (2017). Learning, memorizing or both? - Autonomy of education; A comparative analysis. Journal of Human Work and Management, 4(2), 1-12.

Wang, S.-M., Hou, H.-T., \& Wu, S.-Y. (2017). Analyzing the knowledge construction and cognitive patterns of blog-based instructional activities using four frequent interactive 
strategies (problem solving, peer assessment, role playing and peer tutoring): A preliminary study. Educational Technology Research and Development, 65(2), 301-323. https://doi.org/10.1007/s11423-016-9471-4

Wickersham, L., \& Dooley, K. (2006). A content analysis of critical thinking skills as an indicator of quality of online discussion in virtual learning communities. Quarterly Review of Distance Education, 7(2), 185-193.

Williams, L., \& Lahman, M. (2011). Online discussion, student engagement, and critical thinking. Journal of Political Science Education, 7(2), 143-162.

Winne, P. H. (1995). Self-regulation is ubiquitous but its forms vary with knowledge. Educational Psychologist, 30(4), 223-228.

Wise, A. F., Perera, N., Hsiao, Y.-T., Speer, J., \& Marbouti, F. (2012). Microanalytic case studies of individual participation patterns in an asynchronous online discussion in an undergraduate blended course. The Internet and Higher Education, 15(2), 108-117.

Yew, E. H. J., \& Yong, J. J. Y. (2014). Student perceptions of facilitators' social congruence, use of expertise and cognitive congruence in problem-based learning. Instructional Science, 42(5), 795-815. https://doi.org/10.1007/s11251-013-9306-1

Yin, R. K. (1994). Case Study Research: Design and Methods (2nd ed., Applied Social Research Methods Series, v. 5). Thousand Oaks, California: Sage Publications.

Yuan, J., \& Kim, C. (2014). Guidelines for facilitating the development of learning communities in online courses. Journal of Computer Assisted Learning, 30(3), 220-232. https://doi.org/10.1111/jcal.12042 
Yuan, J., \& Kim, C. (2017). The effects of autonomy support on student engagement in peer assessment. Educational Technology Research and Development. https://doi.org/10.1007/s11423-017-9538-x

Zha, S., \& Ottendorfer, C. L. (2011). Effects of peer-led online asynchronous discussion on undergraduate students' cognitive achievement. American Journal of Distance Education, 25(4), 238-253. https://doi.org/10.1080/08923647.2011.618314

Zhao, H., Sullivan, K. P. H., \& Mellenius, I. (2014). Participation, interaction and social presence: An exploratory study of collaboration in online peer review groups. British Journal of Educational Technology, 45(5), 807-819.

Zhu, E. (2006). Interaction and cognitive engagement: An analysis of four asynchronous online discussions. Instructional Science, 34(6), 451-480.

Zimmerman, B. J., \& Pons, M. M. (1986). Development of a structured interview for assessing student use of self-regulated learning strategies. American Educational Research Journal, 23(4), 614-628. https://oi.org/10.3102/00028312023004614 


\section{APPENDIX A}

\section{Elements of Critical Thinking}

As a discussion leader, when you read your classmates' original posts, refer to the following list to see whether the post reflects their critical thinking.

Does the post:

a. Connect to the associated readings?

b. Connect to the posters' experience (such as work experience, school experience, or internships)?

c. Connect to prior knowledge gained in this or other courses?

d. Show how the poster may apply the concepts to future job experience? 


\section{APPENDIXB \\ B1: Control Group (CG) Interview Questions}

1. Did you make the original post before the deadline every week?

2. How many comments did you make every week on average?

3. Did you ask questions in response to other student's comments?

4. How much time, on average, did you spend composing a discussion post?

5. Did you read peoples comments on your discussion?

6. Did you respond to people's comments on your posts?

7. What are you learning through the discussions?

8. In your original posts or comments on other students' posts, did you connect to the reading?

9. In your original posts or comments on other students' posts, did you connect what you posted to the course content in previous weeks?

10. In your original posts or comments on other students' posts, did you connect what you posted to your own work experience/internship experience?

11. In your original posts or comments on other students' posts, did you connect what you posted to other courses in your major and/or minor?

12. Do you know why you are being asked to participate in discussions?

13. Do you like how online discussion is organized and managed in this class?

14. Do you enjoy the online discussion?

15. Is there a time you feel frustrated with online discussion?

16. What would make your experience with discussion assignments better? 


\section{B2: Experimental Group (EG) Interview Questions}

1B. What did you do when you facilitated the discussion as the leader?

- Synopsis

- Facilitation strategy

- Initial two questions

2B. How did you participate in student-led online discussion? Can you walk me through your process each week?

- individual approach

3B. When did you typically make your original post each week?

4B. How many comments, on average, did you make every week?

5B. How much time, on average, did you spend composing a discussion post?

6B. Did you read peoples comments on your discussion posts?

- Were they helpful?

- Did they add to the conversation?

- What would have made them better?

7B. Did you respond to people's comments on your posts?

- Why/why not?

8C. What are you learning through the discussions?

9C. In your original posts or comments on other students' posts, did you connect to:

- the reading from the week?

- the course content in previous weeks?

- your own work experience/internship experience?

- other courses in your major and/or minor? 
10C. In your opinion, why you are being asked to participate in discussions?

11E. Please comment on how online discussion is organized and managed in this class?

12E. How do you like leading the student-led online discussion?

- Synopsis

- Questions

- Discussion facilitation strategy

- The elements of critical thinking list/Peer assessment

- Emotional reactions

- participation

13E. How do you like participating in the student-led online discussion?

- Synopsis posted by leaders

- Discussion facilitation, in general

- The questions leaders asked

- Instructor participation

14E. Did you prefer leading the discussion or participating in the discussion better?

15. Comment on the student-led discussion verses traditional discussion.

16E. Did you experience difficulty when leading the discussion?

17E. What would you improve about student-led discussion? 


\section{APPENDIXC \\ C1: Pre-survey (Both CG and EG)}

AEQ (Pekrun et al, 2011)

Students rate their emotional experiences on a five point Likert scale from 1- strongly disagree, 2- somewhat disagree, 3- neither agree nor disagree, 4- somewhat agree, and 5-strongly agree.

Enjoyment

1. I enjoy my online discussions.

2. I enjoy online discussions so much that I am strongly motivated to participate.

3. I am happy that I understand the readings required for online discussion.

4. I enjoy doing discussions so much that I am motivated to make extra discussion posts and comments.

5. I think that online discussions are going great.

Pride

1. I am proud of my contributions to the online discussions.

2. I am very motivated because I want to be proud of my achievements in online discussions.

Anger

1. I am annoyed during online discussions.

2. I get angry because the discussions occupy so much of my time.

3. I am annoyed that the discussion questions are so difficult. Anxiety

1. When thinking about my online discussions, I get nervous.

2. I worry if the material related to online discussion is much too difficult for me.

3. I worry whether I will ever be able to completely understand the material related to online discussion.

4. I'm so scared of my class discussions that I would rather not start them.

5. I am nervous about my discussion posts.

6. I am so anxious that I can't fully concentrate on my discussion posts. Shame

1. I am ashamed that I cannot answer discussion questions well.

2. When I say something in my online discussions, I feel like I am embarrassing myself.

3. I am embarrassed about my lack of knowledge in the online discussion topics.

4. When I don't understand something in my online discussions, I don't want to tell anybody.

Boredom

1. I think the online discussion is boring.

2. Just thinking of my online discussion assignments makes me feel bored.

3. I'm so bored by online discussion that I don't feel like studying any more. 
MSLQ (Pintrich \& de Groot, 1990)

The survey response format is a seven-point Likert scale which ranges from 1 (not at all true to me) to 7 (very true of me).

Self-Regulated Learning Strategies

D. Cognitive Strategy Use

1. When I create original posts and make comments on other students' posts, I try to put together the information from class and from the book.

2. When I create original posts and make comments on other students' posts, I try to remember what the teacher says in class so I can pose questions that will engage my classmates.

3. It is hard for me to decide what the main ideas are in what I read and post.

4. When I create original posts and make comments on other students' posts I put important ideas into my own words.

5. I always try to understand what the discussion questions are asking even if it doesn't make sense to me.

6. When I create original posts and make comments on other students' posts I try to remember as many facts as I can.

7. When I create original posts and make comments on other students' posts I mentally review the important facts of the readings.

8. I use what I learn from the readings and other classes to create original posts and make comments on other students' posts.

9. When I post a discussion, I try to make readings, past discussions, past course content, and personal experience fit together.

10. When posting I try to connect the things I am learning with things I already know. 


\section{C2: CG Post-Survey}

AEQ (Pekrun et al., 2011)

Students rate their emotional experiences on a five point Likert scale from 1- strongly disagree,

2-somewhat disagree, 3-neither agree nor disagree, 4- somewhat agree, and 5- strongly agree.

Enjoyment

1. I enjoyed my online discussions.

2. I enjoyed online discussions so much that I was strongly motivated to participate.

3. I was happy that I understood the readings required for online discussion.

4. I enjoyed doing discussions so much that I was motivated to make extra discussion posts and comments.

5. I think that online discussions went great.

Pride

1. I was proud of my contributions to the online discussions.

2. I was very motivated because I wanted to be proud of my achievements in online discussions.

Anger

1. I was annoyed during online discussions.

2. I got angry because the discussions occupied so much of my time.

3. I was annoyed that the discussion questions were so difficult.

\section{Anxiety}

1. When thinking about my online discussions, I got nervous.

2. I worried if the material related to online discussion was much too difficult for me.

3. I worried whether I would ever be able to completely understand the material related to online discussion.

4. I was so scared of my class discussions that I would rather not start them.

5. I was nervous about my discussion posts.

6. I was so anxious that I couldn't fully concentrate on my discussion posts.

Shame

1. I was ashamed that I could not answer discussion questions well.

2. When I said something in my online discussions, I felt like I was embarrassing myself.

3. I was embarrassed about my lack of knowledge in the online discussion topics.

4. When I didn't understand something in my online discussions, I didn't want to tell anybody.

Boredom

1. I thought the online discussion was boring. 
2. Just thinking of my online discussion assignments made me feel bored.

3. I was so bored by online discussion that I didn't feel like studying any more.

MSLQ (Pintrich \& de Groot, 1990)

The survey response format is a seven-point Likert scale which ranges from 1 (not at all true to me) to 7 (very true of me).

Self-Regulated Learning Strategies

D. Cognitive Strategy Use

1. When I created original posts and made comments on other students' posts, I tried to put together the information from class and from the readings.

2. When I created original posts and made comments on other students' posts, I tried to remember what the teacher said in class so I could pose questions that would engage my classmates.

3. It is hard for me to decide what the main ideas were in what I read and posted.

4. When I created original posts and made comments on other students' posts I put important ideas into my own words.

5. I always try to understand what the discussion questions were asking even if it didn't make sense to me.

6. When I created original posts and made comments on other students' posts I tried to remember as many facts as I can.

7. When I created original posts and made comments on other students' posts I mentally reviewed the important facts of the readings.

8. I use what I have learned from the readings and other classes to create original posts and make comments on other students' posts.

9. When I post a discussion, I tried to make readings, past discussions, past course content, and personal experience fit together.

10. When posting I tried to connect the things I am learning with things I already know. 


\section{C3: EG Post-Survey}

AEQ (Pekrun et al, 2011)

Students rate their emotional experiences on a five point Likert scale from 1- strongly disagree,

2-somewhat disagree, 3-neither agree nor disagree, 4- somewhat agree, and 5- strongly agree.

Enjoyment

1. I enjoyed leading online discussion (including posting synopsis, facilitating the discussion, and assessing other students' posts and commenting on their posts).

2. I enjoyed participating in the online discussions led by other groups.

3. I enjoyed student-led online discussions so much that I was strongly motivated to participate.

4. I was happy that I understood the readings required for online discussion and could apply the concepts when leading discussions or interacting with peer leaders.

5. I enjoyed doing student-led discussions so much that I was motivated to make extra discussion posts and comments.

6. I think that student-led online discussions went great.

Pride

1. I was proud of my contributions to the student-led online discussions.

2. I was very motivated because I wanted to be proud of my achievements in student-led online discussions.

3. I enjoyed leading online discussion (including posting synopsis, facilitating the discussion, and assessing other students' posts and commenting on their posts) and also participating in the discussions led by other groups so much that I was strongly motivated to work on these tasks.

Anger

1. I was annoyed during student-led online discussions.

2. I got angry because the student-led discussions occupied so much of my time.

3. I was annoyed that the student-led discussion questions were so difficult.

4. I was annoyed that the instructor was not leading discussions.

Anxiety

1. When thinking about my student-led online discussions, I got nervous.

2. I worried if the material related to online discussion was much too difficult for me.

3. I worried whether I would ever be able to completely understand the material related to online discussion.

4. I worried whether I would ever be able to completely understand the student-led discussions.

5. I was so scared of my student-led discussions that I would rather not start them.

6. I was nervous about my student-led discussion posts.

7. I was so anxious that I couldn't fully concentrate on my student-led discussion posts. Shame

1. I was ashamed that I could not create discussion questions well. 
2. When I said something in my student-led online discussions, I felt like I was embarrassing myself.

3. I was embarrassed about my lack of knowledge in the online discussion topics.

4. When I didn't understand something in my student-led online discussions, I didn't want to tell anybody.

Boredom

1. I thought the student-led online discussion was boring.

2. Just thinking of my student-led online discussion assignments made me feel bored.

3. I was so bored by online discussion that I didn't feel like posting discussions or comments any more.

MSLQ (Pintrich \& de Groot, 1990)

The survey response format is a seven-point Likert scale which ranges from 1 (not at all true to me) to 7 (very true of me).

Self-Regulated Learning Strategies

D. Cognitive Strategy Use

1. When I created the synopsis and original posts and made comments on other students' posts, I try to put together the information from class and from the book.

2. When I created the synopsis and original posts and made comments on other students' posts, I try to remember what the teacher said in class so I can pose questions that will engage my classmates.

3. It is hard for me to decide what the main ideas are in what I read and post.

4. When I created the synopsis and original posts and made comments on other students' posts, I put important ideas into my own words.

5. I always try to understand what the discussion questions are asking even if it doesn't make sense to me.

6. When I created the synopsis and original posts and made comments on other students' posts, I try to remember as many facts as I can.

7. When I created the synopsis and original posts and made comments on other students' posts, I mentally review the important facts of the readings.

8. I use what I have learned from the readings and other classes to create the synopsis and original posts and made comments on other students' posts. 
9. When I post a discussion, I try to make readings, past discussions, past course content, and personal experience fit together.

10. When posting I try to connect the things I am learning with things I already know. 
APPENDIXD

Rubrics

D1

Rubric to Evaluate Leaders Initial Submission

\begin{tabular}{|c|c|c|c|}
\hline Criteria & Requirements not met & Satisfactory & Excellent \\
\hline $\begin{array}{l}\text { Synopsis/ } \\
\text { reflection } \\
\text { (10 points) }\end{array}$ & $\begin{array}{l}\text { Synopsis does not support } \\
\text { understanding of content } \\
\text { and required readings. } \\
\text { Nothing to support } \\
\text { opinions. }\end{array}$ & $\begin{array}{l}\text { Synopsis discusses main } \\
\text { ideas of content, with no } \\
\text { additional development. } \\
\text { Reflection is not available. }\end{array}$ & $\begin{array}{l}\text { Synopsis provides a } \\
\text { comprehensive overview of } \\
\text { the content. Opinions are } \\
\text { clearly stated. Participants } \\
\text { reflect on the content and } \\
\text { relate it to prior lessons and } \\
\text { practical application. }\end{array}$ \\
\hline $\begin{array}{l}\text { Discussion } \\
\text { question } \\
\text { ( } 8 \text { points) }\end{array}$ & $\begin{array}{l}\text { Discussion question is not } \\
\text { open ended or relevant to } \\
\text { specific content and } \\
\text { facilitation strategy is not } \\
\text { identified. }\end{array}$ & $\begin{array}{l}\text { One discussion question } \\
\text { only and/or facilitation } \\
\text { strategy not identified. }\end{array}$ & $\begin{array}{l}\text { Two open-ended discussion } \\
\text { questions provided and } \\
\text { facilitation strategy clearly } \\
\text { identified. }\end{array}$ \\
\hline $\begin{array}{l}\text { Facilitation } \\
\text { strategy } \\
\text { selection } \\
\text { (3 points) }\end{array}$ & $\begin{array}{l}\text { Facilitation strategy is not } \\
\text { clearly identified and is } \\
\text { the not the best choice for } \\
\text { the discussion questions } \\
\text { provided. }\end{array}$ & $\begin{array}{l}\text { Facilitation strategy is } \\
\text { clearly identified OR is the } \\
\text { best choice for the } \\
\text { discussion questions } \\
\text { provided. }\end{array}$ & $\begin{array}{l}\text { Facilitation strategy is clearly } \\
\text { identified and is the best } \\
\text { choice for the discussion } \\
\text { questions provided. }\end{array}$ \\
\hline $\begin{array}{l}\text { Quality of } \\
\text { writing } \\
\text { (4 points) }\end{array}$ & $\begin{array}{l}\text { Numerous grammatical, } \\
\text { spelling, or punctuation } \\
\text { errors. Effective } \\
\text { communication is not } \\
\text { achieved. }\end{array}$ & $\begin{array}{l}\text { Some grammatical, } \\
\text { spelling, or punctuation } \\
\text { errors, which may be } \\
\text { distracting to the reader. }\end{array}$ & $\begin{array}{l}\text { Free of grammatical, spelling, } \\
\text { or punctuation errors. } \\
\text { Effective communication of } \\
\text { ideas. }\end{array}$ \\
\hline
\end{tabular}

Note. Course policy is that all late work receives a score of zero. If the leader turns in work late, they will be graded only on the facilitation criteria. 
D2

Rubric to Evaluate Leaders Facilitation

\begin{tabular}{|c|c|c|c|}
\hline $\begin{array}{l}\text { Facilitation } \\
(20 \text { points ) }\end{array}$ & $\begin{array}{l}\text { Does not provide } \\
\text { responses to posts. } \\
\text { Discussion postings rarely } \\
\text { contribute to conversation } \\
\text { or show critical thinking. } \\
\text { Some interactions show } \\
\text { respect or interest in } \\
\text { viewnoints of others. }\end{array}$ & $\begin{array}{l}\text { Responds to few posts } \\
\text { and does not enhance } \\
\text { discussion through } \\
\text { critical thinking. Most } \\
\text { interactions show respect } \\
\text { and interest in the } \\
\text { viewpoints of others. }\end{array}$ & $\begin{array}{l}\text { Responds to many posts } \\
\text { and enhances critical } \\
\text { thinking of other } \\
\text { participants. Creates } \\
\text { further discussion. } \\
\text { Interactions show respect } \\
\text { and sensitivity to peers. }\end{array}$ \\
\hline
\end{tabular}

Note. Course policy is that all late work receives a score of zero. If the leader turns in work late, they will be graded only on the facilitation criteria.

D3

Rubric to Evaluate Other Participants' Performances

\begin{tabular}{|c|c|c|c|}
\hline Criteria & Requirements not met & Satisfactory & Excellent \\
\hline $\begin{array}{l}\text { Critical } \\
\text { Analysis/ } \\
\text { Relation to the } \\
\text { Profession/ } \\
\text { Course Content } \\
\text { (5 points) }\end{array}$ & $\begin{array}{l}\text { Posts do not support } \\
\text { understanding of } \\
\text { content. Nothing to } \\
\text { support opinions, such } \\
\text { as additional resources } \\
\text { or examples. }\end{array}$ & $\begin{array}{l}\text { Posts discuss main ideas of } \\
\text { content, with no additional } \\
\text { development. Supporting } \\
\text { material and/or opinions are } \\
\text { not available. }\end{array}$ & $\begin{array}{l}\text { Posts show an excellent } \\
\text { understanding of the } \\
\text { content. Additional } \\
\text { resources and specific } \\
\text { examples are cited and } \\
\text { integrated to support main } \\
\text { ideas. Opinions are clear. }\end{array}$ \\
\hline $\begin{array}{l}\text { Quality of } \\
\text { Writing } \\
\text { (5 points) }\end{array}$ & $\begin{array}{l}\text { Numerous } \\
\text { grammatical, spelling, } \\
\text { or punctuation errors. } \\
\text { Effective } \\
\text { communication not } \\
\text { achieved. }\end{array}$ & $\begin{array}{l}\text { Some grammatical, spelling, } \\
\text { or punctuation errors, which } \\
\text { may be distracting to the } \\
\text { reader. }\end{array}$ & $\begin{array}{l}\text { Free of grammatical, } \\
\text { spelling, or punctuation } \\
\text { errors. Effective } \\
\text { communication of ideas. }\end{array}$ \\
\hline $\begin{array}{l}\text { Responses } \\
(5 \text { points) }\end{array}$ & $\begin{array}{l}\text { Does not provide } \\
\text { response to posts nor } \\
\text { contributes to ongoing } \\
\text { conversation. Some } \\
\text { interactions show } \\
\text { respect and interest in } \\
\text { the viewpoints of } \\
\text { others. }\end{array}$ & $\begin{array}{l}\text { Does not responds to one } \\
\text { post and does not answer } \\
\text { questions posed by leaders. } \\
\text { Enhances discussion. Most } \\
\text { interactions show respect or } \\
\text { interest in the viewpoints of } \\
\text { others. }\end{array}$ & $\begin{array}{l}\text { Responds to one post. } \\
\text { Answers questions posed by } \\
\text { student leaders in response } \\
\text { to original post. Discussion } \\
\text { posting creates further } \\
\text { discussion. Interactions } \\
\text { show respect and sensitivity } \\
\text { to peers' opinions, } \\
\text { background, and beliefs. }\end{array}$ \\
\hline
\end{tabular}

Note. Course policy is that all late work receives a score of zero. If the participants turn in work late, they will be graded only on the responses criteria (unless that is also late). 


\section{APPENDIXE}

\section{EG Blocks Compared to CG}

\begin{tabular}{|c|c|c|c|c|c|c|c|c|c|c|c|c|c|c|c|c|c|c|c|c|c|}
\hline \multirow[b]{2}{*}{ Variable } & \multicolumn{3}{|c|}{$\begin{array}{c}C G \\
n=29\end{array}$} & \multicolumn{3}{|c|}{$\begin{array}{c}\text { Block } 1 \\
n=4\end{array}$} & \multicolumn{3}{|c|}{$\begin{array}{c}\text { Block } 2 \\
n=4\end{array}$} & \multicolumn{3}{|c|}{$\begin{array}{c}\text { Block } 3 \\
n=3\end{array}$} & \multicolumn{3}{|c|}{$\begin{array}{c}\text { Block } 4 \\
n=5\end{array}$} & \multicolumn{3}{|c|}{$\begin{array}{c}\text { Block } 5 \\
n=4\end{array}$} & \multicolumn{3}{|c|}{$\begin{array}{c}\text { Block } 6 \\
n=3\end{array}$} \\
\hline & $\mathrm{M}$ & SD & $95 \% \mathrm{Cl}$ & $\mathrm{M}$ & SD & $95 \% \mathrm{Cl}$ & $M$ & SD & $95 \% \mathrm{Cl}$ & $\mathrm{M}$ & SD & $95 \% \mathrm{Cl}$ & $M$ & SD & $95 \% \mathrm{Cl}$ & $M$ & SD & $95 \% \mathrm{Cl}$ & $M$ & SD & $95 \% \mathrm{Cl}$ \\
\hline Cognitive & 5.38 & 0.8 & $\begin{array}{r}5.07 \\
5.69]\end{array}$ & 5.85 & 0.5 & $\begin{array}{l}{[5.10} \\
6.60]\end{array}$ & 5.1 & 0.3 & $\begin{array}{r}4.63 \\
5.57]\end{array}$ & 6 & 0.8 & $\begin{array}{r}4.06 \\
7.94]\end{array}$ & 5.48 & 0.4 & $\begin{array}{r}5.00 \\
5.96]\end{array}$ & 5.7 & 0.5 & $\begin{array}{r}4.90 \\
6.50]\end{array}$ & 5 & 1.1 & $\begin{array}{r}2.20 \\
7.80]\end{array}$ \\
\hline Enjoyment & 3.14 & 0.96 & $\begin{array}{r}{[2.81} \\
3.48]\end{array}$ & 3.75 & 0.89 & $\begin{array}{l}{[2.33} \\
5.17]\end{array}$ & 3.31 & 1.05 & $\begin{array}{r}{[1.64,} \\
4.98]\end{array}$ & 3.50 & 1.00 & $\begin{array}{r}{[1.02} \\
5.98]\end{array}$ & 3.35 & 1.23 & $\begin{array}{r}{[1.82} \\
4.88]\end{array}$ & 3.31 & 0.77 & $\begin{array}{r}{[2.08} \\
4.54]\end{array}$ & 2.75 & 0.90 & $\begin{array}{r}{[0.51} \\
4.99]\end{array}$ \\
\hline Anxiety & 3.61 & 1.10 & $\begin{array}{r}{[3.23} \\
4.00]\end{array}$ & 3.58 & 0.22 & $\begin{array}{l}{[3.24} \\
3.93]\end{array}$ & 3.33 & 1.43 & $\begin{array}{r}{[1.05,} \\
5.61]\end{array}$ & 4.11 & 1.54 & $\begin{array}{r}{[0.29} \\
7.94]\end{array}$ & 3.40 & 1.30 & $\begin{array}{r}{[1.78} \\
5.02]\end{array}$ & 3.38 & 0.83 & $\begin{array}{r}{[2.05} \\
4.70]\end{array}$ & 3.61 & 1.42 & $\begin{array}{r}{[0.09} \\
7.13]\end{array}$ \\
\hline Shame & 3.65 & 1.13 & $\begin{array}{r}{[3.26} \\
4.05]\end{array}$ & 3.94 & 1.09 & $\begin{array}{l}{[2.21} \\
5.67]\end{array}$ & 3.63 & 1.38 & $\begin{array}{r}{[1.43} \\
5.82]\end{array}$ & 4.50 & 0.87 & $\begin{array}{r}{[2.35} \\
6.65]\end{array}$ & 3.80 & 1.36 & $\begin{array}{r}{[2.11} \\
5.49]\end{array}$ & 3.75 & 0.68 & $\begin{array}{r}{[2.67} \\
4.83]\end{array}$ & 3.92 & 1.28 & $\begin{array}{r}{[0.73} \\
7.10]\end{array}$ \\
\hline Boredom & 3.31 & 1.07 & $\begin{array}{r}{[2.94} \\
3.69]\end{array}$ & 3.83 & 1.00 & $\begin{array}{l}{[2.24} \\
5.42]\end{array}$ & 3.08 & 1.34 & $\begin{array}{r}{[0.95} \\
5.22]\end{array}$ & 4.33 & 0.58 & $\begin{array}{r}{[2.90} \\
5.77]\end{array}$ & 3.47 & 1.22 & $\begin{array}{r}{[1.96} \\
4.98]\end{array}$ & 3.17 & 1.11 & $\begin{array}{r}{[1.41} \\
4.93]\end{array}$ & 2.67 & 1.53 & $\begin{array}{r}{[-1.13} \\
6.46]\end{array}$ \\
\hline Pride & 3.75 & 0.95 & $\begin{array}{r}{[3.45} \\
4.08]\end{array}$ & 4.25 & 0.65 & $\begin{array}{l}{[3.22} \\
5.28]\end{array}$ & 3.63 & 0.63 & $\begin{array}{r}{[2.62} \\
4.63]\end{array}$ & 4.33 & 1.15 & $\begin{array}{r}{[1.46} \\
7.20]\end{array}$ & 3.70 & 0.91 & $\begin{array}{r}{[2.57} \\
4.83]\end{array}$ & 3.63 & 1.03 & $\begin{array}{r}{[1.98} \\
5.27]\end{array}$ & 3.67 & 0.58 & $\begin{array}{r}{[2.23} \\
5.10]\end{array}$ \\
\hline Anger & 3.42 & 0.91 & $\begin{array}{l}{[3.1} \\
3.74]\end{array}$ & 4.17 & 0.79 & $\begin{array}{l}{[2.90} \\
5.43]\end{array}$ & 3.25 & 1.26 & $\begin{array}{r}{[1.25} \\
5.25]\end{array}$ & 4.22 & 0.51 & $\begin{array}{r}{[2.96} \\
5.49]\end{array}$ & 4.20 & 0.77 & $\begin{array}{r}{[3.25} \\
5.15]\end{array}$ & 3.58 & 0.92 & $\begin{array}{r}{[2.12} \\
5.04]\end{array}$ & 2.89 & 0.38 & $\begin{array}{r}\text { [1.93, } \\
3.85]\end{array}$ \\
\hline \multirow[t]{2}{*}{$\begin{array}{r}\text { Academic } \\
\text { Performance } \\
\end{array}$} & 13.22 & 1.73 & $\begin{array}{r}{[12.56,} \\
13.88]\end{array}$ & 12.88 & 2.17 & $\begin{array}{l}{[12.56,} \\
13.88]\end{array}$ & 11.94 & 3.43 & $\begin{array}{l}{[9.41} \\
16.34]\end{array}$ & 11.42 & 5.99 & $\begin{array}{l}{[6.48} \\
17.40]\end{array}$ & 11.50 & 2.11 & $\begin{array}{l}{[-3.47} \\
26.30]\end{array}$ & 14.44 & 1.39 & $\begin{array}{l}{[8.88} \\
14.12]\end{array}$ & 11.33 & 0.38 & $\begin{array}{r}{[12.23,} \\
16.65]\end{array}$ \\
\hline & \multicolumn{3}{|c|}{$\begin{array}{c}\text { Block } 7 \\
n=2\end{array}$} & \multicolumn{3}{|c|}{$\begin{array}{c}\text { Block } 8 \\
n=5\end{array}$} & \multicolumn{3}{|c|}{$\begin{array}{c}\text { Block } 9 \\
n=3\end{array}$} & \multicolumn{3}{|c|}{$\begin{array}{c}\text { Block } 10 \\
n=5\end{array}$} & \multicolumn{3}{|c|}{$\begin{array}{c}\text { Block } 11 \\
n=5\end{array}$} & \multicolumn{3}{|c|}{$\begin{array}{c}\text { Block } 12 \\
n=4\end{array}$} & & & \\
\hline Variable & $M$ & SD & $95 \% \mathrm{Cl}$ & $M$ & SD & $95 \% \mathrm{Cl}$ & $M$ & SD & $95 \% \mathrm{Cl}$ & $M$ & SD & $95 \% \mathrm{Cl}$ & $M$ & SD & $95 \% \mathrm{Cl}$ & $M$ & SD & $95 \% \mathrm{Cl}$ & $\mathrm{F}$ & $p$ & \\
\hline Cognitive & 5.3 & 0.4 & $\begin{array}{r}1.49 \\
9.11]\end{array}$ & 5.3 & 1.2 & $\begin{array}{r}3.77 \\
6.83]\end{array}$ & 6.03 & 0.6 & $\begin{array}{r}4.54 \\
7.53]\end{array}$ & 5.5 & 0.6 & $\begin{array}{r}4.77 \\
6.23]\end{array}$ & 5.1 & 0.6 & $\begin{array}{r}4.40 \\
5.80]\end{array}$ & 6.15 & 0.4 & $\begin{array}{r}5.46 \\
6.84]\end{array}$ & 1.02 & 0.4 & \\
\hline Enjoyment & 3.50 & 0.35 & $\begin{array}{r}{[0.32} \\
6.68]\end{array}$ & 3.45 & 1.23 & $\begin{array}{r}{[1.92,} \\
4.98]\end{array}$ & 4.00 & 0.25 & $\begin{array}{r}{[3.38} \\
4.62]\end{array}$ & 3.50 & 0.56 & $\begin{array}{r}{[2.81} \\
4.19]\end{array}$ & 3.70 & 0.74 & $\begin{array}{r}{[2.78} \\
4.62]\end{array}$ & 3.44 & 0.97 & $\begin{array}{r}{[1.90} \\
4.97]\end{array}$ & 0.51 & 0.90 & \\
\hline Anxiety & 4.17 & 1.18 & $\begin{array}{l}{[-6.42,} \\
14.76]\end{array}$ & 4.07 & 1.00 & $\begin{array}{r}{[2.82} \\
5.31]\end{array}$ & 2.61 & 0.95 & $\begin{array}{r}{[0.26} \\
4.97]\end{array}$ & 4.30 & 1.10 & $\begin{array}{r}{[2.94} \\
5.66]\end{array}$ & 3.57 & 1.16 & $\begin{array}{r}{[2.12} \\
5.01]\end{array}$ & 4.25 & 0.96 & $\begin{array}{r}{[2.73} \\
5.77]\end{array}$ & 0.67 & 0.77 & \\
\hline Shame & 4.13 & 1.24 & $\begin{array}{l}{[-6.99,} \\
15.24]\end{array}$ & 4.10 & 0.89 & $\begin{array}{r}{[2.99 .} \\
5.21]\end{array}$ & 3.25 & 0.66 & $\begin{array}{r}{[1.61} \\
4.89]\end{array}$ & 4.35 & 0.86 & $\begin{array}{r}{[3.28} \\
5.42]\end{array}$ & 4.00 & 1.00 & $\begin{array}{r}{[2.76,} \\
5.24]\end{array}$ & 4.44 & 0.97 & $\begin{array}{r}{[2.90} \\
5.97]\end{array}$ & 0.50 & 0.91 & \\
\hline Boredom & 3.00 & 0.00 & $\begin{array}{r}{[3.00} \\
3.00]\end{array}$ & 3.67 & 1.41 & $\begin{array}{r}{[1.91} \\
5.42]\end{array}$ & 3.56 & 0.19 & $\begin{array}{r}{[3.08} \\
4.03]\end{array}$ & 3.53 & 1.12 & $\begin{array}{r}{[2.14} \\
4.92]\end{array}$ & 4.07 & 0.80 & $\begin{array}{r}{[3.08} \\
5.05]\end{array}$ & 3.75 & 1.45 & $\begin{array}{r}{[1.44} \\
6.06]\end{array}$ & 0.63 & 0.81 & \\
\hline Pride & 4.00 & 0.00 & $\begin{array}{r}{[4.00,} \\
4.00]\end{array}$ & 3.70 & 1.30 & $\begin{array}{r}{[2.08,} \\
5.32]\end{array}$ & 4.33 & 1.15 & $\begin{array}{r}{[1.46} \\
7.20]\end{array}$ & 4.20 & 0.57 & $\begin{array}{r}{[3.49} \\
4.91]\end{array}$ & 4.10 & 0.55 & $\begin{array}{r}{[3.42} \\
4.78]\end{array}$ & 3.88 & 0.85 & $\begin{array}{r}{[2.52} \\
5.23]\end{array}$ & 0.41 & 0.95 & \\
\hline Anger & 3.00 & 0.47 & $\begin{array}{r}{[-1.24} \\
7.24]\end{array}$ & 3.93 & 1.48 & $\begin{array}{r}{[2.10} \\
5.77]\end{array}$ & 3.67 & 1.00 & $\begin{array}{r}{[1.18} \\
6.15]\end{array}$ & 4.00 & 0.85 & $\begin{array}{r}{[2.94} \\
5.06]\end{array}$ & 3.87 & 0.77 & $\begin{array}{r}{[2.91} \\
4.82]\end{array}$ & 4.25 & 0.74 & $\begin{array}{r}{[3.07} \\
5.43]\end{array}$ & 1.11 & 0.37 & \\
\hline $\begin{array}{r}\text { Academic } \\
\text { Performance }\end{array}$ & 9.38 & 5.83 & $\begin{array}{r}{[10.38} \\
12.28]\end{array}$ & 14.55 & 1.12 & $\begin{array}{r}{[-43.04,} \\
61.79]\end{array}$ & 13.17 & 2.55 & $\begin{array}{c}{[6.82} \\
19.51]\end{array}$ & 13.50 & 1.85 & $\begin{array}{r}{[11.21} \\
15.79]\end{array}$ & 12.05 & 1.92 & $\begin{array}{l}{[9.67} \\
14.43]\end{array}$ & 12.88 & 1.80 & $\begin{array}{r}{[10.02} \\
15.73]\end{array}$ & 1.38 & 0.20 & \\
\hline
\end{tabular}

${ }^{\text {a }}$ Possible range of cognitive engagement: 1-7

${ }^{\mathrm{b}}$ Possible range of emotional engagement: 1-5 
APPENDIXF

\section{Randomized Block Design}

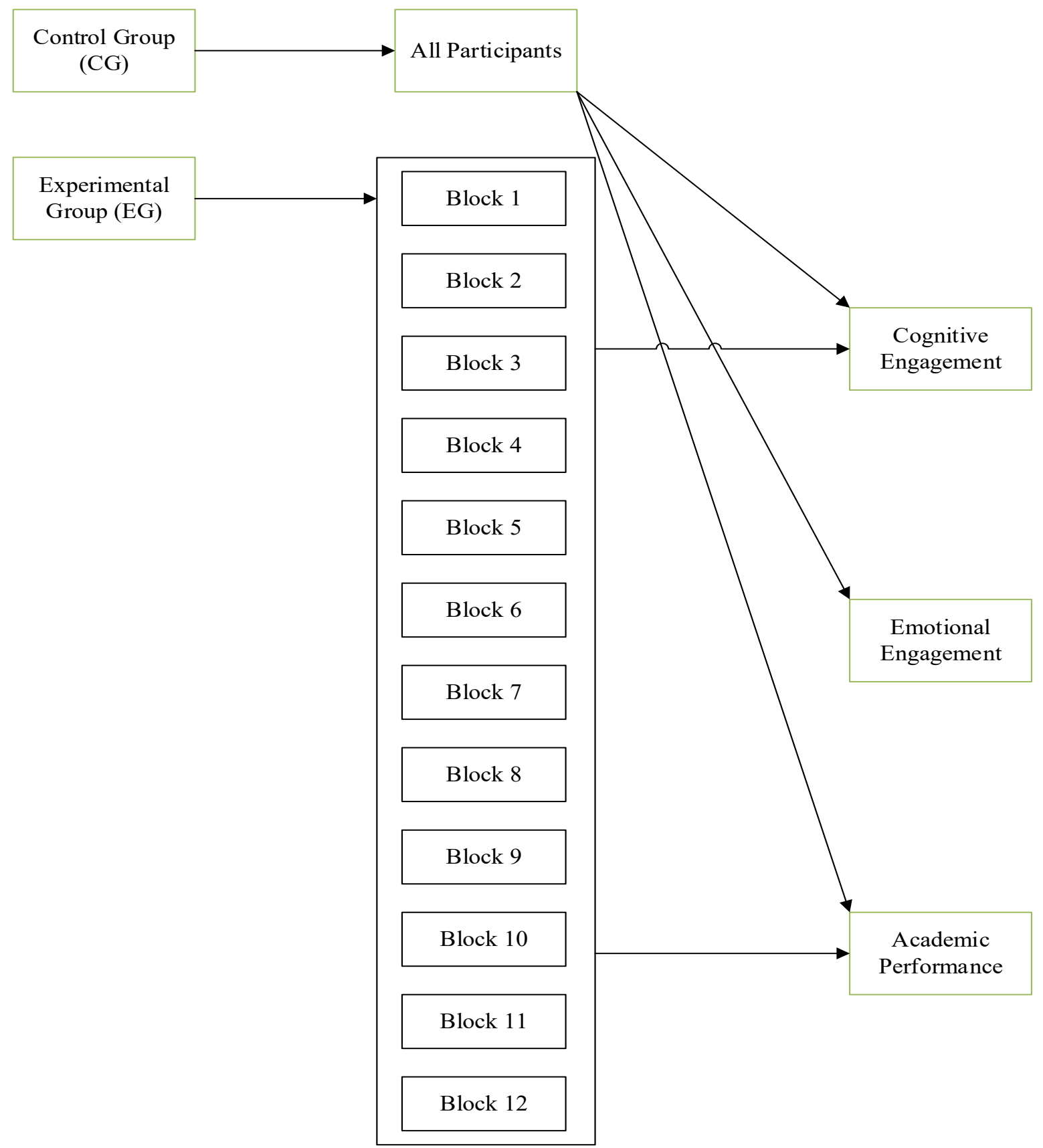

